\title{
Single particle characterization of black carbon aerosols at a tropospheric alpine site in Switzerland
}

\author{
D. Liu ${ }^{1}$, M. Flynn ${ }^{1}$, M. Gysel ${ }^{2}$, A. Targino ${ }^{1}$, I. Crawford ${ }^{1}$, K. Bower ${ }^{1}$, T. Choularton ${ }^{1}$, Z. Jurányi ${ }^{2}$, M. Steinbacher ${ }^{3}$, \\ C. Hüglin $^{3}$, J. Curtius ${ }^{4}$, M. Kampus ${ }^{4}$, A. Petzold ${ }^{5}$, E. Weingartner ${ }^{2}$, U. Baltensperger ${ }^{2}$, and H. Coe ${ }^{1}$ \\ ${ }^{1}$ Centre for Atmospheric Science, School of Earth, Atmospheric and Environmental Sciences, University of Manchester, \\ M13 9PL, UK \\ ${ }^{2}$ Laboratory of Atmospheric Chemistry, Paul Scherrer Institut, 5232 Villigen PSI, Switzerland \\ ${ }^{3}$ EMPA Überlandstrasse 1298600 Dübendorf, Switzerland \\ ${ }^{4}$ Institute for Atmospheric Physics, Johannes Gutenberg University, Mainz, Germany \\ ${ }^{5}$ Deutsches Zentrum für Luft- und Raumfahrt (DLR), Institut für Physik der Atmosphäre, Oberpfaffenhofen, \\ 82234 Wessling, Germany
}

Received: 1 March 2010 - Published in Atmos. Chem. Phys. Discuss.: 7 April 2010

Revised: 4 July 2010 - Accepted: 2 August 2010 - Published: 9 August 2010

\begin{abstract}
The refractory black carbon (rBC) mass, size distribution (190-720 nm) and mixing state in submicron aerosols were characterized from late February to March 2007 using a single particle incandescence method at the high alpine research station Jungfraujoch (JFJ), Switzerland $\left(46.33^{\circ} \mathrm{N}, 7.59^{\circ} \mathrm{E}, 3580 \mathrm{~m}\right.$ a.s.1.). JFJ is a ground based location, which is at times exposed to continental free tropospheric air. A median mass absorption coefficient (MAC) of $10.2 \pm 3.2 \mathrm{~m}^{2} \mathrm{~g}^{-1}$ at $\lambda=630 \mathrm{~nm}$ was derived by comparing single particle incandescence measurements of black carbon mass with continuous measurements of absorption coefficient. This value is comparable with other estimates at this location. The aerosols measured at the site were mostly well mixed and aged during transportation via the free troposphere. Pollutant sources were traced by air mass back trajectories, trace gases concentrations and the mass loading of rBC. In southeasterly wind directions, mixed or convective weather types provided the potential to vent polluted boundary layer air from the southern Alpine area and industrial northern Italy, delivering enhanced $\mathrm{rBC}$ mass loading and $\mathrm{CN}$ concentrations to the JFJ. The aerosol loadings at this site were also significantly influenced by precipitation, which led to the removal of $\mathrm{rBC}$ from the atmosphere. Precipitation events were shown to remove about $65 \%$ of the rBC mass from the free tropospheric background reducing the mean loading from $13 \pm 5 \mathrm{ng} \mathrm{m}^{-3}$ to $6 \pm 2 \mathrm{ng} \mathrm{m}^{-3}$ (corrected
\end{abstract}

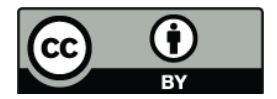

Correspondence to: D. Liu (dantong.liu@ postgrad.manchester.ac.uk) to standard temperature and pressure). Overall, $40 \pm 15 \%$ of the observed $\mathrm{rBC}$ particles within the detectable size range were mixed with large amounts of non-refractory materials present as a thick coating. The growth of particle size into the accumulation mode was positively linked with the degree of rBC mixing, suggesting the important role of condensable materials in increasing particle size and leading to enhanced internal mixing of these materials with $\mathrm{rBC}$. It is the first time that $\mathrm{BC}$ mass, size distribution and mixing state are reported in the free troposphere over Europe. These ground based measurements also provide the first temporal study of $\mathrm{rBC}$ in the European free troposphere quantitatively measured by single particle methods. At the present time there is only limited information of $\mathrm{BC}$ and its mixing state in the free troposphere, especially above Europe. The results reported in this paper provide an important constraint on modelled representation of BC.

\section{Introduction}

The chemical composition of aerosols plays an important role in determining their hygroscopic and optical properties, which are key factors in determining the cloud activation and the aerosol radiative effect respectively. The black carbon (BC) particle fraction is extremely important because it is insoluble and is a strong light absorber at mid-visible and near infrared wavelengths (Bond and Bergstrom, 2006). It has been considered as having the second most important

Published by Copernicus Publications on behalf of the European Geosciences Union. 
warming influence after carbon dioxide (Ramanathan and Carmichael, 2008). BC is produced through a range of combustion processes that are not fully completed (Bond et al., 2004), e.g. fossil fuel combustion and biomass burning. It is refractory and initially hydrophobic (e.g. Weingartner et al., 1997), and this combined with its size distribution being biased towards the fine mode (Harris and Maricq, 2001; Kondo et al., 2006; Clarke et al., 2004), means that BC is less efficiently scavenged compared with other more hydrophilic and larger particles. After emission into the atmosphere, BC is processed by the condensation of secondary material such as sulfates, nitrates or organic matter, increasing the size and hygroscopicity of the particles (e.g. Dusek et al., 2006a). During atmospheric ageing, the refractory component of BC is chemically quite stable and so is relatively invariant, making $\mathrm{BC}$ an tracer of primary pollution, though its mixing state changes markedly. It has been used to compare the extent to which secondary material has formed on a particle population, i.e. by comparing with the relative amount of organic aerosols (Turpin and Huntzicker, 1995).

The sink of $\mathrm{BC}$ is primarily governed by wet deposition (Textor et al., 2006; Jacobson, 2004). The atmospheric lifetime of $\mathrm{BC}$ is particularly controlled by the time scale for $\mathrm{BC}$ to be converted from its initial hydrophobic state to a hydrophilic state. Modelling and observational studies have revealed that $\mathrm{BC}$ is more likely to act as a cloud condensation nucleus $(\mathrm{CCN})$ at much lower critical sizes if coated (Henson, 2007; Dusek et al., 2006a), but this will depend on the composition of the coating material (Petzold et al., 2005a). However, due to the systematic limitations of most of the current bulk-based BC measurements (Collaud Coen et al., 2010), direct examination of BC mixing state is not possible. Furthermore, treating BC as internally or externally mixed can result in large differences in predictions of the global radiative budget (e.g. Chung and Seinfeld, 2002), due to the enhancement of the mass absorption efficiency when BC is internally mixed (Bond et al., 2006 and references therein). The impact of $\mathrm{BC}$ absorption can be further amplified when deposited on snow (Hansen and Nazarenko, 2004) or incorporated into cloud particles (Jacobson, 2006) because of the high reflectivity of the surrounding material.

The $\mathrm{BC}$ content of an aerosol layer has great impact on the positive radiative forcing of the solar-atmosphere system in the upper troposphere/lower stratosphere (UT/LS) because of its absorption of direct solar radiation (Ramanathan and Carmichael, 2008), in addition, it has the potential to be involved in ice nucleation, consequently reducing the cloud coverage to weaken the indirect cooling effect (Lohmann, 2002). The extent to which $B C$ can be transported from ground sources to the UT/LS is highly dependent on its mixing state, as convection and frontal uplift provide the main mechanisms for transport from the boundary layer, during which the hydrophilic BC can be more efficiently removed via wet deposition. Alternatively, BC can be directly injected into the UT/LS by aircraft emissions at high altitude. How- ever, a recent study by Hendricks et al. (2004) showed that the contribution from aircraft emissions in the UT/LS is minor but that different predicted BC size distributions lead to different impacts. Schwarz et al. (2008a) obtained profiles of BC from near-ground atmosphere to UT/LS in the tropical US, and observed that BC with a thicker and prevalent coating would result in absorption enhancement of at least $30 \%$ in the upper troposphere compared to $\mathrm{BC}$ that is assumed to be uncoated. These studies highlight the important contribution of $\mathrm{BC}$ from ground sources via vertical transport and the desirability to investigate the mixing state of BC.

To address questions related to the size distribution and mixing state of BC in sub-micron aerosols, a study was conducted at the Sphinx Laboratory of the Jungfraujoch highalpine research station $\left(46.33^{\circ} \mathrm{N}, 7.59^{\circ} \mathrm{E}, 3580 \mathrm{~m}\right.$ a.s.1.), Switzerland. The research station is located at the northern side of the main central European Alpine area, and provides an ideal site to study aerosols which have been transported to the free troposphere from a large range of sources across Europe and northern Africa. The site also receives pollution from local valleys primarily during the summer months. The transported particles contain considerable amounts of secondary material, as well as processed and/or relatively fresher primary particles. The refractory $\mathrm{BC}$ particles $(\mathrm{rBC})^{1}$ in the accumulation mode were characterized via a single particle soot photometer (SP2), which also measured the optical size of both $\mathrm{rBC}$ and non-absorbing particles. The instrument is highly sensitive to low concentrations of aerosols, providing a clear segregation of $\mathrm{rBC}$ from other types of aerosols, and additionally can be used to derive information regarding the mixing state of $\mathrm{rBC}$ on a single particle basis. This paper investigates the behaviour of $\mathrm{rBC}$ at this site in a late winter season, considers the particle lifetime, and describes how removal processes relate to the size distribution of $\mathrm{rBC}$ and its mixing state. It was the first time that the behaviour of $\mathrm{BC}$ has been investigated on a particle by particle basis in the lower free troposphere over Europe.

\section{Site description and meteorological conditions}

The data presented in this paper was sampled during the sixth experiment within the CLoud and Aerosol Characterization Experiments (CLACE6) programme conducted at the Jungfraujoch (JFJ) research station in the winter of 2007. This measurement site is surrounded by glaciers and rocks, and no local vegetation is present. The location and altitude make this site far remote from significant pollution

\footnotetext{
${ }^{1}$ With respect to the terminology of $\mathrm{BC}$, the incandescence channel of the SP2 (Sect. 3.2) measures the refractory black carbon (rBC) (Schwarz et al., 2010) as opposed to the light absorbing carbon (suggested by Bond and Bergstrom, 2006), or BC that is most often used in models or derived from filter based optical absorption measurement. Therefore the $\mathrm{rBC}$ is used in this paper to consistently define the $\mathrm{BC}$ properties measured using this instrument.
} 
sources and the local emissions from the station and the tourist facilities are negligible since all heating is electrical (Baltensperger et al., 1997) and other combustion sources are kept at a minimum.

During summer, the local meteorology and topography exert a predominant influence on the JFJ. The site is influenced by a combination of valley-mountain and mountain up-slope circulations, giving a clear diurnal cycle of aerosol concentrations as a result of the injection of planetary boundary layer air into the free troposphere air during the afternoon. On occasion, the JFJ site can also be a receptor of pollutants from regional sources, for example from the Po Valley caused by ascent of air from the convective boundary layer. This mainly occurs under subsidence conditions associated with the presence of an anticyclone over the Alps (Lugauer et al., 1998, 2000). Vertical transport tends to be more frequent during the summer months but has also been observed in wintertime (Zellweger et al., 2003). During the winter months, the convective processes are much less vigorous and aerosol concentrations are mostly controlled by regional and long-range tropospheric circulation systems (Baltensperger et al., 1997; Lugauer et al., 1998). The long-term aerosol measurements from this site have been thoroughly analyzed and reported by Baltensperger et al. (1997) and Collaud Coen et al. (2007).

Continuous aerosol sampling was conducted during CLACE6 from mid February 2007 to mid March 2007. For most of this time, the high-alpine site was receiving remote continental/marine air masses from the free troposphere, but under the influence of varying anticyclonic air systems, pollutants from different regions of Europe and Atlantic Ocean (Fig. 1, A1-A5) were observed. The dominant local horizontal wind directions measured by a sonic anemometer (Metek, manufactured by Lymington, UK) were observed to be from either the north $(\mathrm{N})$ or southeast (SE) (Fig. 1, B). This wind pattern has been observed in other studies and is due to the JFJ location between the Jungfrau $(4158 \mathrm{~m})$ and Mönch $(4089 \mathrm{~m})$ mountains, channelling the local flow in a north-western or south-eastern direction. In the northerly wind direction, air from the Swiss plateau is advected to the Jungfraujoch, while in south-easterly winds, the air comes from the southern Alpine area and industrial northern Italy. Alfarra et al. (2007) have shown that many rural regions in the Alps rely on wood burning for home heating during the winter and this provides a significant source of particulate in this season. However, the site was subjected to periods of heavy precipitation during the first half of the experiment, resulting in a considerable fraction of aerosols being washed out. Clouds were present at the site for approximately $60 \%$ of the experimental period. The phase of the cloud varied from periods when liquid-water clouds were dominant to periods when the clouds were almost entirely composed of ice particles. The aerosols sampled at this site experienced a combination of precipitation and cloud processing.
The aerosol data were also analysed as a function of the synoptic weather types defined by Schüepp (1979) in the Alpine Weather Statistic (AWS), which is a synoptic weather type parameterization that describes the synoptic meteorology over the whole Swiss region. The classification is based on the combination of four key parameters (Wanner et al., 1998): 1) speed of the surface wind derived from the surface pressure gradient, 2) direction and speed of the $500 \mathrm{hPa}$ wind, 3 ) height of the $500 \mathrm{hPa}$ surface over the central point of the system, 4) baroclinicity. This results in 40 weather situations which can be grouped into three basic weather types (convective, advective, mixed) and eight extended weather types (Table 1). For the advective types, the horizontal motion of the atmosphere is dominant (which in Alpine areas may lead to well marked up-slope and lee phenomena, e.g. Föhn), while for convective types vertical motion is dominant. For the mixed weather type, both horizontal and vertical wind components are significant. Lugauer et al. $(1998,2000)$ showed that these weather types had a strong influence on the aerosol signal at the Jungfraujoch.

\section{Instrumentation, sampling and data analysis methodology}

\subsection{Sampling inlet}

Aerosol particles were sampled using an inlet system mounted on a platform above the Sphinx Laboratory. This sampling inlet was fitted with a heater $\left(25^{\circ} \mathrm{C}\right)$ on its upstream end, which was designed to evaporate cloud particles with an aerodynamic diameter smaller than $40 \mu \mathrm{m}$ at wind speeds up to $20 \mathrm{~m} \mathrm{~s}^{-1}$ (Weingartner et al., 1999). Larger particles may penetrate the inlet at lower wind speeds, thus both the particles incorporated into cloud particles and non-activated interstitial aerosols can be sampled. The instruments were located behind the inlet system in the laboratory at room temperature and the aerosols were sampled under dry conditions (Relative Humidity $<20 \%$ ). A separate inlet system close to the aerosol inlet was used for the observation of gaseous species. It consists of a stainless steel tube (inner diameter $90 \mathrm{~mm}$ ) heated to $10^{\circ} \mathrm{C}$ and ventilated at $850 \mathrm{~L} \mathrm{~min}^{-1}$, a glass manifold (inner diameter $40 \mathrm{~mm}$ ) flushed with $250 \mathrm{~L} \mathrm{~min}^{-1}$ and perfluoroalkoxy (PFA) teflon tubes to connect the instruments to the glass inlet.

\subsection{The instrumentation}

The physical properties of $\mathrm{rBC}$ were characterized by a single particle soot photometer (SP2, manufactured by Droplet Measurement Technologies $\bigcirc$, DMT, Boulder, USA). The SP2 can optically size particles in the diameter range $200 \mathrm{~nm}-720 \mathrm{~nm}$. An intra-cavity Nd:YAG laser beam (Stephens et al., 2003) $\left(1.064 \mu \mathrm{m}, \mathrm{TEM}_{\mathrm{oo}}\right.$ mode, intensity $\sim 1 \mathrm{MW} \mathrm{cm}^{-2}$ ) is used for particle detection on a single particle basis (Schwarz et al., 2006). As particles pass 


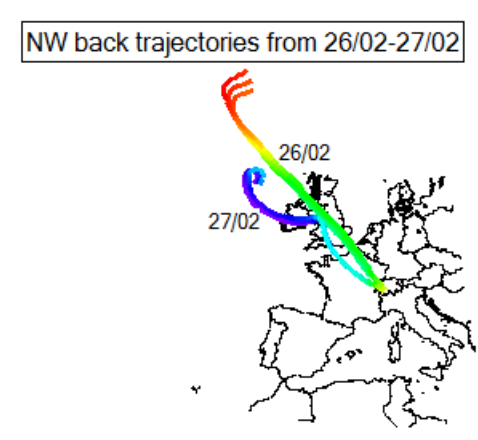

A1

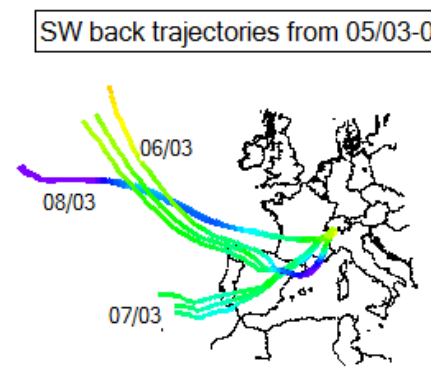

A3

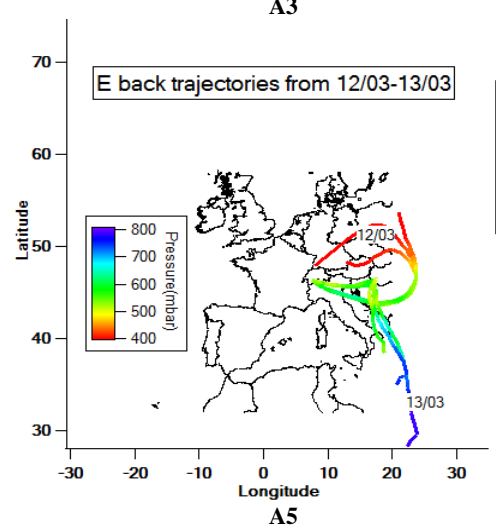

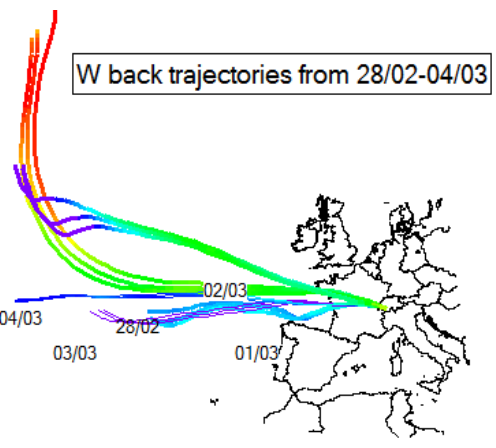

A2

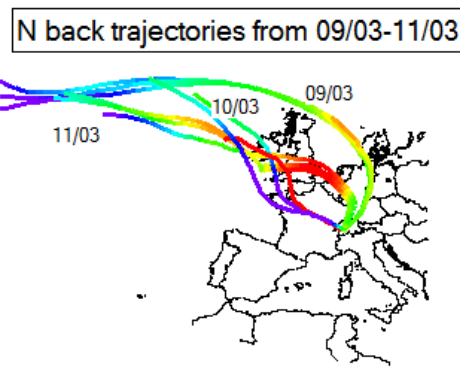

A4

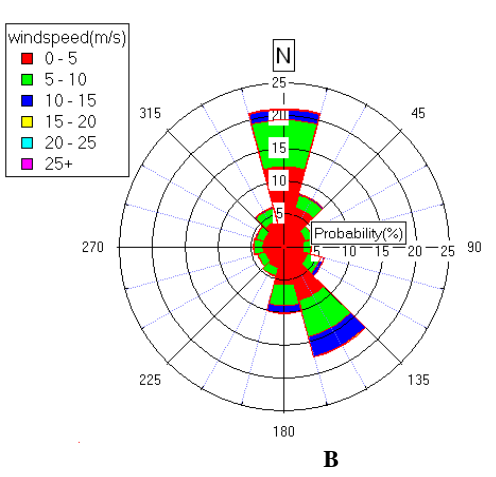

Fig. 1. The experimental site was influenced by air mass history and local wind direction (A1-A5), back trajectory analysis calculated by NOAA Hybrid Single-Particle Lagrangian Integrated Trajectory model (HYSPLIT; Draxler, 2003). Time periods are classified according to the history of the air mass over the previous three days. Back trajectories are shown for arrival at $3400 \mathrm{~m}, 3600 \mathrm{~m}$ and $3800 \mathrm{~m}$ a.s. 1 . over the Jungfraujoch, labelled by the arriving date and are coloured by air pressure. (B) Wind rose plot for the whole experiment period, individual wind direction measurements are accumulated and the relative frequency is shown as a percentage. The plot is coloured according to the probability of wind speed.

through the laser beam they scatter the laser light and hence their optical size can be determined by analyzing the peak amplitude of the scattered light signal. If the particle contains strongly absorbing components, such as BC, it also absorbs the laser radiation and is heated, thus exceeding the boiling temperatures of any non-refractory coatings, before the refractory absorbing core eventually incandesces and emits significant thermal radiation. The emitted black body radiation is proportional to the mass of the absorber and the boiling point of the absorbing core is characteristic of the compo- sition of the particle (Schwarz et al., 2006). Incandescence radiation is measured using two detectors, one has a broad bandwidth and the other is set at a narrow bandwidth close to the maximum of the blackbody radiation emitted by incandescing $\mathrm{rBC}$. The ratio of signals from these two detectors provides information on the temperature of the incandescing particle and hence its composition. Two further detectors characterize the intensity of the scattered laser radiation. All detectors record the evolution of single particle-laser interactions simultaneously with a time resolution of $0.2 \mu$ s. 
Table 1. The 3 basic and 8 extended types of the Alpine weather statistics and their dominant synoptic scale motion.

\begin{tabular}{lllll}
\hline $\begin{array}{l}\text { Basic weather } \\
\text { type }\end{array}$ & $\begin{array}{l}\text { Extended } \\
\text { types }\end{array}$ & Abbreviation & Synoptic motion & $\begin{array}{l}\text { Occurrence during } \\
\text { this study }\end{array}$ \\
\hline Convective & Anticyclonic & CA & Subsidence & $19 \%$ \\
& Indifferent & CI & $\begin{array}{l}\text { Small-scale } \\
\text { circulations }\end{array}$ & $18 \%$ \\
& Cyclonic & CC & lifting & \\
Advective & West & AW & W at $500 \mathrm{hPa}$ & $45 \%$ \\
& North & AN & NW-N at $500 \mathrm{hPa}$ & \\
& East & AE & NE-SE at $500 \mathrm{hPa}$ & \\
& South & AS & S-SW at $500 \mathrm{hPa}$ & \\
Mixed & Mixed & M & $\begin{array}{l}\text { Active cyclone or } \\
\text { jet flow or vortex }\end{array}$ & $18 \%$ \\
\hline
\end{tabular}

The particles are classified as $\mathrm{rBC}$ or non-BC according to the presence of the incandescence signal.

The mass determination of $\mathrm{rBC}$ by the SP2 has been observed to be independent of particle shape (Slowik et al., 2007) and the coating components of rBC to a large extent (Moteki and Kondo, 2007). Hence the SP2 can be calibrated by absorbing particles whose mass can be determined. The incandescence signal was calibrated using commercially available standard glassy carbon spheres (supplied by Alpha Aesar, Inc., Ward Hill, Massachusetts, with density $1.42 \mathrm{gcm}^{-3}$ ), which were size-selected by introducing a differential mobility analyzer (DMA) upstream of the SP2 down to single particle mass loadings of about $12 \mathrm{fg}$. Multi-charged particles were rejected using the scattering signal measured by the SP2. The calibration between the rBC mass and peak intensity of the incandescence signal was shown to be linear $\left(R^{2}=0.97\right)$ when single rBC mass is below $130 \mathrm{fg}$, agreeing with the laboratory results by Slowik et al. (2007). The composition of the absorbing component of ambient particles was determined from the ratio of the two incandescence signals, in turn $\mathrm{rBC}$ particles were identified and their mass was determined from the calibrated peak intensity of the incandescence signal. The diameter of the $\mathrm{rBC}$ core is termed as the mass equivalent diameter $\left(D_{\mathrm{ME}}\right)$, since it is determined from the mass, and given by:

$D_{\mathrm{ME}}=\left(6 M / \rho_{\mathrm{BC}} \pi\right)^{1 / 3}$

Where $M$ is the particle refractory mass derived from incandescence signal with uncertainty $\pm 5-9 \%, \rho_{\mathrm{BC}}$ is used as the average effective density of atmospheric $\mathrm{rBC}\left(1.9 \mathrm{gcm}^{-3}\right)$ recommended by Bond and Bergstrom (2006). In reality, $\mathrm{BC}$ is likely to be irregular in shape thus $D_{\mathrm{ME}}$ provides a minimum estimation of the surface of the atmospheric soot particle. This uncertainty is significantly reduced when thick coatings are present which restructure the $\mathrm{BC}$ by compacting soot aggregates (Weingartner et al., 1995).

Monodispersed polystyrene latex spheres (PSL, refractive index $\sim 1.59$, Gao et al., 2007) of known sizes were used to calibrate the scattering signal and monitor the laser intensity throughout the experiment. Laser power variation was less than $10 \%$ during the entire operation period of the SP2, resulting in variations of optical size of less than $6 \%$. Additionally, Baumgardner et al. (2007) point out the uncertainty in the derived optical diameter is within $\pm 30 \mathrm{~nm}$, assuming the coating is sulphate. Overall, the optical diameter $\left(D_{\mathrm{O}}\right)$ of non-absorbing particles can be determined from PSL calibration with uncertainty about $\pm 8 \%$ within size range 200 $720 \mathrm{~nm}$ for this study, and the optical size below or above the SP2 detection limit will not be triggered or saturate the detectors respectively.

The $D_{\mathrm{O}}$ for absorbing particles can be underestimated because the particle size will begin to decrease before it reaches the centre of the laser beam as the coating material evaporates, which means the detected scattering signal does not correctly represent the original optical size. An extrapolation technique can overcome this problem by applying a detectable laser beam center position and fixed signal distribution shape (Gao et al., 2007). This needs a hardware modification that had not been carried out on the instrument at the time of the experiment. The uncertainty of optical sizing of $\mathrm{rBC}$ is estimated to be about $6-55 \%$ by comparing the scattering signal of $\mathrm{rBC}$ and non-absorbing particles of the same size in the laboratory study afterwards. This effect is more significant for larger $\mathrm{rBC}$ cores and with higher volatility of 
coating materials. In addition, soot aggregation can enhance the scattering property significantly (Liu and Mishchenko, 2005). The mass fraction (MF) of a $\mathrm{rBC}$ core of mass $M$, is calculated by Eq. (2):

$\mathrm{MF}=\frac{M}{\frac{1}{6} \pi D_{\mathrm{O}}^{3} \rho_{\mathrm{av}}}$

The average density of a particle $\left(\rho_{\mathrm{av}}\right)$ used in this study was $1.8 \mathrm{~g} \mathrm{~cm}^{-3}$, following Cross et al. (2007). The uncertainty of the density can vary with coating composition by approximately $41 \%$ from pure sulfate to organic. However, in reality the coating is typical multi-component. The overall uncertainty for $M$ resulting from the $\rho_{\mathrm{av}}$ is estimated to be $\pm 23 \%$.

A significant number of $\mathrm{rBC}$ particles are smaller than the lower detection limit of the SP2, which is about $190 \mathrm{~nm}$ in this study ( $\sim 6 \mathrm{fg} \mathrm{rBC}$ mass), leading to systematic underestimation of $\mathrm{rBC}$ mass. To account for this, previous studies have estimated the total $\mathrm{BC}$ by extrapolating the mass size distribution according to a single lognormal mode (Schwarz et al., 2006). A similar approach is applied to the dataset presented in this paper (constrained at the modal centre, diameter $190-210 \mathrm{~nm}$, Fig. 8a), where about $40-60 \%$ mass or $30 \%$ number of the entire $\mathrm{rBC}$ population has been detected by the SP2. The mass or number concentrations of $\mathrm{rBC}$ presented in this paper have been corrected for these effects, and are quoted at standard temperature and pressure (STP; $273.15 \mathrm{~K}$, $1013.25 \mathrm{hpa}$ ). The larger $\mathrm{rBC}$ particles that saturate the detectors represent about $0.2-0.6 \%$ of the total population of $\mathrm{rBC}$, which is of minor importance in influencing the derived rBC total mass loading, and this fraction showed little variation under different conditions during this study.

In addition to the characterization by the SP2, a MultiAngle Absorption Photometer (MAAP, Thermo ESM Andersen) was employed to quantify the aerosol light absorption coefficient $\sigma_{\mathrm{abs}}$. The MAAP measured the transmission and the back scattering of a light beam at a defined wavelength ( $\lambda=630 \mathrm{~nm}$ during this experiment) through a fibre filter, where the aerosol is sampled continuously and simultaneously. The light absorption coefficient is obtained from a radiative transfer scheme which corrects for artefacts caused by the interaction of the light with the filter material and offaxis detection at multiple angles is used to correct for the effect of scattering (Petzold and Schönlinner, 2004; Petzold et al., 2005b).

A Condensation Particle Counter (CPC, TSI 3010 model) measured the condensation nucleus $(\mathrm{CN})$ concentration of all sub-micron aerosols with a diameter greater than $10 \mathrm{~nm}$. Therefore a measure of the sub-micron/accumulation mode ratio can be derived from the ratio of the particle numbers measured by the $\mathrm{CPC}$ and the SP2. The $\mathrm{rBC}$ number fraction is defined as the $\mathrm{rBC}$ number concentration measured by the SP2 relative to the CN concentration. Additionally, continuous observations of atmospheric trace gases such as carbon monoxide $(\mathrm{CO})$ and nitrogen oxides $\left(\mathrm{NO}_{\mathrm{x}}\right)$ were continuously performed as part of the Swiss National Air Pollution Monitoring Network.

Precipitation type was measured by the VPF-730 present weather sensor (BIRAL, UK). This instrument primarily determines the precipitation type by the measured ratio of the atmospheric back scattering coefficient to the atmospheric forward scattering coefficient. A ratio greater than a specific value indicates snow while a ratio lower than a threshold value indicates rain. As a secondary approach, the size and velocity distributions of the precipitation particles complement this primary measurement to provide information on different precipitation types. The precipitation particles are counted by measuring the amplitude and duration of the light pulse created by each precipitation particle as its falls through the sample volume. Small numbers of particles with distributions not indicative of rain or snow are considered not to be precipitation and are rejected by false alarm algorithms.

\section{Results and discussions}

\section{1 rBC mass loading and absorption property}

Figure 2 presents the time evolution of total $\mathrm{rBC}$ mass loading measured by SP2 and the light absorption coefficient determined by the MAAP during the entire experiment, indicating a general positive correlation between both instruments, as Fig. 3a further reveals.

Due to the indirect measurement of $\mathrm{BC}$ mass by the MAAP, an empirical converter, which is defined as mass absorption cross section (MAC) (Bond and Bergstrom, 2006), is needed to translate the measured light absorption coefficient of bulk aerosols into the estimated BC mass. The absorption coefficient measured by the MAAP is obtained from the reported mass concentration multiplied by the MAAP internal MAC of $6.6 \mathrm{~m}^{2} \mathrm{~g}^{-1}$ (Petzold et al., 2005b). A variety of uncertainties can be propagated by this empirical conversion, because the MAC of $\mathrm{BC}$ is not a constant, rather it is associated with different sources and combustion conditions (Schwarz et al., 2008b), and is highly influenced by the wavelength, size and mixing state of BC (Bond et al., 2006), i.e. the absorbing efficiency can be enhanced as much as $50 \%$ by an internal coating. Because of the capacity of the SP2 to directly measure the rBC mass concentration, the value of MAC can be derived through the following relationship involving the MAAP measured light absorption coefficient and the $\mathrm{rBC}$ mass concentration $\left(\mathrm{MAC}=\sigma_{\mathrm{abs}} / \mathrm{Mass}_{\mathrm{BC}}\right)$. The distribution of the MAC values for the $\mathrm{BC}$ particles measured in this study is presented in Fig. 3b. A median value $10.2 \pm 3.2 \mathrm{~m}^{2} \mathrm{~g}^{-1}$ of MAC at $\lambda=630 \mathrm{~nm}$ is obtained, which is higher than the previously measured results at this site during winter $\left(7.6 \mathrm{~m}^{2} \mathrm{~g}^{-1}\right)$ obtained by Cozic et al. (2008a), but lower than that in the summer $\left(11.1 \mathrm{~m}^{2} \mathrm{~g}^{-1}\right.$ ) (Cozic et al., 2008a). This discrepancy may partly result from the biases of the thermo-optical bulk measurements of the BC mass by 


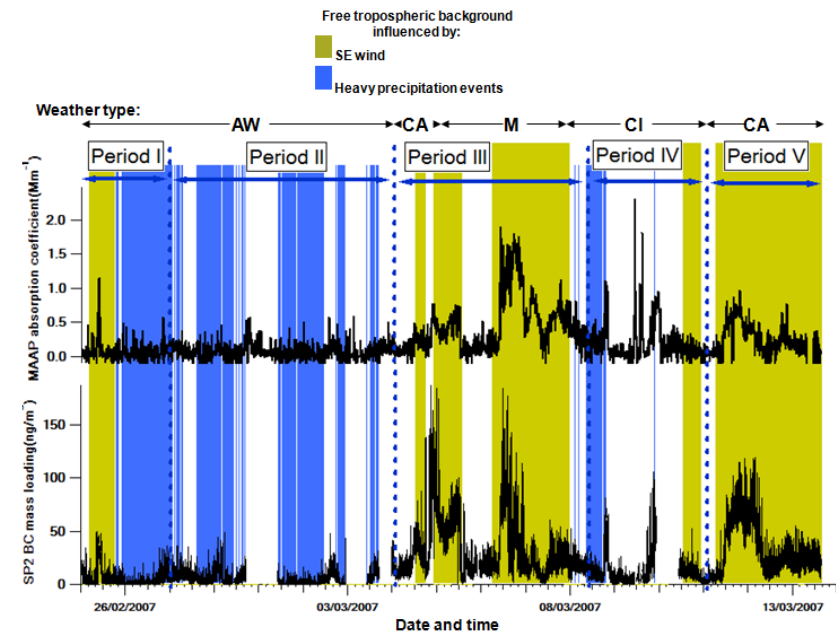

Fig. 2. Time series of total $\mathrm{rBC}$ mass loading from the SP2 and absorption coefficient measured by the Multi-Angle Absorption Photometer (MAAP) for the entire experiment. The five synoptic periods classified by back trajectory analysis (Fig. 1, A1-A5) are separated by dotted lines. The top text line indicates the recognized weather types as detailed in Table 1, with arrows denoting respective periods. Particularly, the time periods when the dominant horizontal wind direction is southeast (SE) are coloured as yellow columns; the dark blue columns mark the periods of heavy precipitation (heavy snow, precipitation particle concentration over $200 \mathrm{~L}^{-1}$ ) as recorded by a present weather sensor.

Cozic et al. (2008a), but can also be caused by the different aerosol sources and varying mixing state of $\mathrm{BC}$, for example, the median MAC observed in this study falls within the reported MAC from biomass burning $\left(13.3 \pm 3.0 \mathrm{~m}^{2} \mathrm{~g}^{-1}\right)$ by Schwarz et al. (2008b), whereas the MAC from urban emission was observed to be much lower $\left(7.5 \pm 2.0 \mathrm{~m}^{2} \mathrm{~g}^{-1}\right)$. Figure $3 \mathrm{~b}$ provides a reference MAC value to translate the measured absorption coefficient to the $\mathrm{BC}$ mass at this site, and gives an estimate of the uncertainty for this conversion.

The uncertainties to determine the MAC values could arise from the random noise of the filter-based measurements and the systematic error to estimate the total $\mathrm{rBC}$ mass loading by extrapolating the SP2 detected mass size distribution with the assumption that the lognormal distribution could represent the rBC modes outside the SP2 detection (Fig. 8a). An inter-comparison study by Slowik et al. (2007) shows that the MAAP measurement of opticallyabsorbing mass was higher by $\sim 50 \%$ than that measured by the SP2, and this discrepancy could be further enhanced by $\sim 20 \%$ when soot was coated, given at this site the aerosols observed have experienced substantial transportation and intense cloud-precipitation scavenging. This may contribute to an overestimation of MAC values. In addition, the presence of light absorbing organic aerosols may also positively bias the conversion between absorption coefficient and BC mass (Lack et al., 2008; Subramanian et al., 2007).
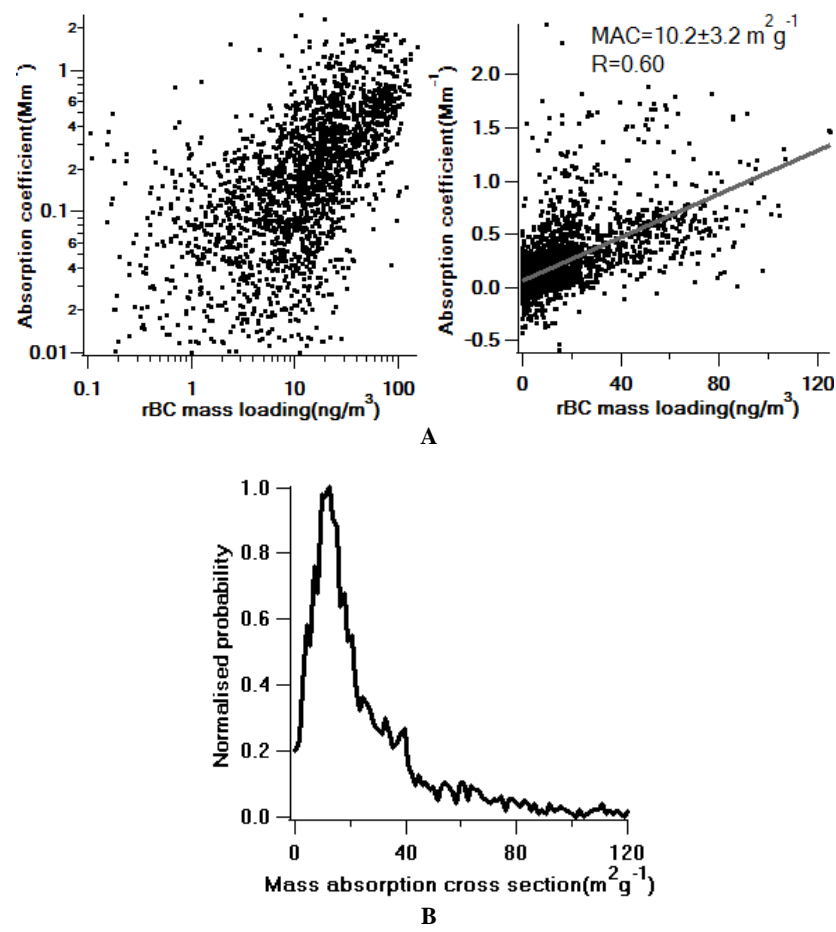

Fig. 3. (A) Correlation between absorption coefficient measured using the MAAP and total $\mathrm{rBC}$ mass loading measured using the SP2, plotted in logarithmic scale (left) and linear scale (right) respectively. The linear regression line and parameters are shown on the linear scale plot. (B) Probability distribution of derived mass absorption cross section (MAC).

\subsection{The determination of $\mathrm{BC}$ mixing state}

The peak incandescence signal of a $\mathrm{rBC}$ particle measured by the SP2 can be delayed relative to the peak scattering signal of the same particle if the $\mathrm{rBC}$ core is surrounded by a coating because the heat generated by the absorption of laser radiation from the absorbing core is used to evaporate the coating before the onset of incandescence. The time delay between the peak intensity of the scattering and incandescence signals gives a measure of the coating evaporation time $(T)$. $T$ has been observed to exhibit a significant increase when rBC is substantially coated (Schwarz et al., 2006; Moteki and Kondo, 2007), which is used to diagnose the mixing state of BC. Figure 4a gives two examples of single rBC particles, both with the same size of $\mathrm{rBC}$ core but with differing abundances of coating components. It can be seen that a thicker coating has increased the scattering signal and $T$ for a given laser intensity.

As the coating on a particle increases, for a fixed $\mathrm{rBC}$ mass the MF will reduce and it is expected that $T$ will increase. This behaviour is indicated in Fig. 4b, showing the 10000 rBC particles collected during the experiment. Little variation in $T$ is observed for particles with a MF above 0.27 , because little time is required to evaporate thin coatings on $\mathrm{rBC}$ 

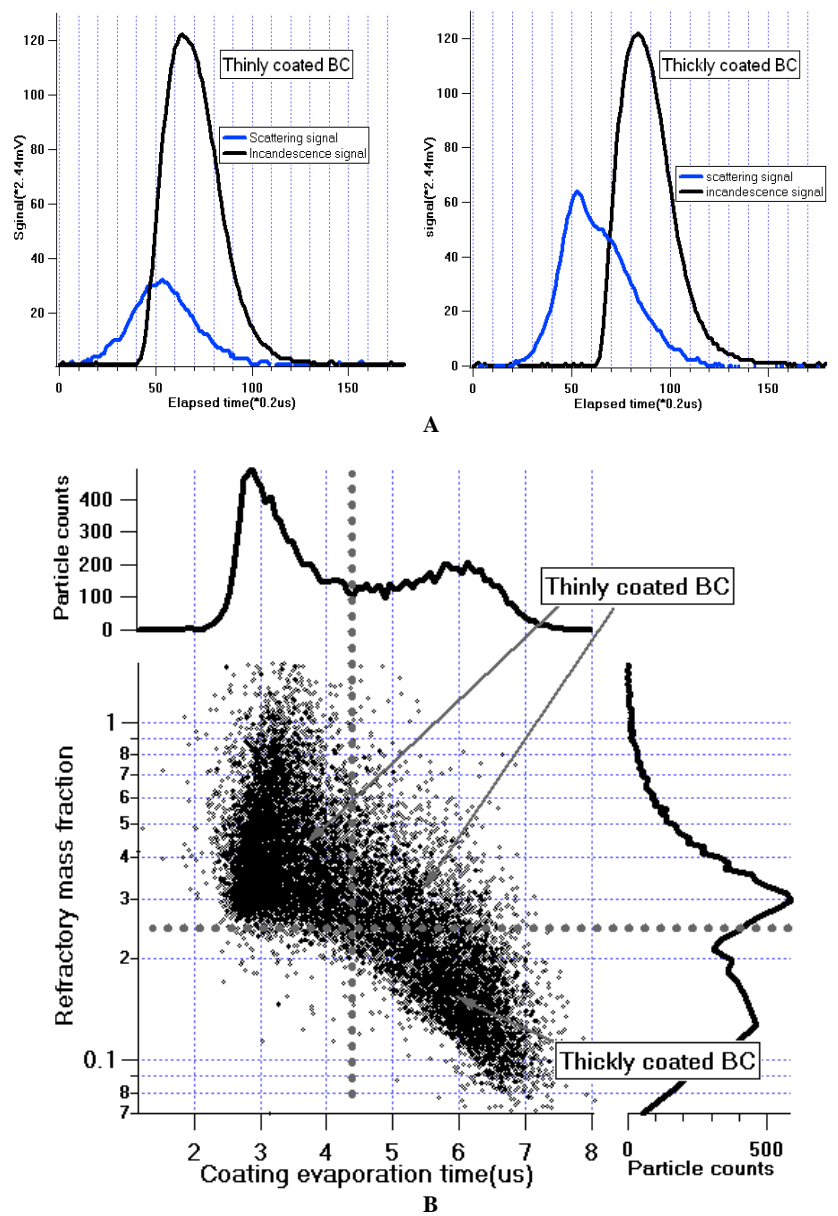

Fig. 4. (A) Two examples of detected $\mathrm{rBC}$ in single particles, both having the same size of $\mathrm{rBC}$ core but the left one is less or relatively thinly coated compared to the thickly coated one on the right. (B) the refractory mass fraction related to the coating evaporation time, the upper and right lines show the histograms of $\mathrm{x}$-axis and $y$-axis values respectively, units are particle counts. The definitions of thickly-coated and thinly-coated BC are illustrated.

cores. These particles have such thin coatings that the definition of $T$ is somewhat uncertain. On the other hand when particle $\mathrm{MF}<27 \%$, coating thicknesses become substantial and more time is required to evaporate them before particle incandescence occurs. Figure $4 \mathrm{~b}$ shows a dramatic increase in $T$ when the coating mass fraction is over $73 \%(\mathrm{MF}<0.27)$. The $\mathrm{rBC}$ particles within this region are likely to be entirely enclosed by relatively thick coatings, delaying the onset of incandescence, and the rest of the $\mathrm{rBC}$ particles tend to be less or relatively thinly coated. $T=4.2 \pm 0.2 \mu$ s is observed to be a critical point above which $T$ is more strongly dependent on MF.

The coating thickness can be estimated assuming sphericity and will be in the range of $0-180 \mathrm{~nm}$ and approaches $60 \pm 15 \mathrm{~nm}$ when $T$ approaches the critical point. The calculated thickness falls within the range of urban observations by Baumgardner et al. (2007) and Moteki and Kondo (2007) $(0-150 \mathrm{~nm})$ using the same approach, but the average is much higher because the particles at this site have been transported a long distance and experienced significant atmospheric ageing. However, the complex morphology of BC makes it difficult to define the coating thickness as the condensed coating layer may not be evenly distributed on the soot aggregates and compaction of the particle shape to a spheroid occurs as a result of atmospheric ageing (Weingartner et al., 1995).

The mixing efficiency (ME) of BC is defined as the fraction of detected absorbing particles which have a thick coating (defined as $\mathrm{MF}<0.27$ as Fig. $4 \mathrm{~b}$ illustrates). The ME is expected to exhibit pronounced size dependence as it is more difficult to condense sufficient material onto larger $\mathrm{rBC}$ cores to obtain a thick coating than it is for small $\mathrm{rBC}$ cores. Previously, these effects were reduced by investigating the mixing state over a fairly narrow range, i.e. close to the median $D_{\mathrm{ME}}$ at 190-210 nm (Schwarz et al., 2008a) where the rBC has a largest population, and assuming that larger and smaller underlying core sizes were nearly bare and had thick coatings respectively. In this experiment the ME for the total measured particulate was compared with that over the limited size range as conducted previously (Schwarz et al., 2008a; Moteki et al., 2007). Figure 5 shows that the ME at the $\mathrm{rBC}$ median size can represent the mixing trend of the entire group of $\mathrm{rBC}$ particles during this experiment, and this approach allows coverage of a wider size range at the expense of the considerable uncertainty in determining the coating thickness of $\mathrm{rBC}$ particles. The slightly lower $M$ derived from the total $\mathrm{rBC}$ compared with that derived from particles close to the median size is due to the reduction in the collection efficiency of the SP2 at the lower detection limit, given small $\mathrm{rBC}$ cores are more likely to be thickly coated.

\subsection{Attributions of pollutant sources by air mass history, weather type and local wind}

The entire experimental period was classified into five phases, each of which has broadly similar local wind direction and similar back trajectories for the past three days. Three arrival altitudes $(3400 \mathrm{~m}, 3600 \mathrm{~m}$ and $3800 \mathrm{~m})$ were chosen for each trajectory calculation, which were run every $6 \mathrm{~h}$ using the NOAA Hybrid Single-Particle Lagrangian Integrated Trajectory model (HYSPLIT; Draxler, 2003). Figure 1 (A1-A5) shows that the JFJ sampling site was dominated by descending air for about $80 \%$ of the experimental period. The trajectories show that during each period, the air masses were transported along broadly consistent pathways. The back trajectories are named according to the directions of originating flows corresponding to each period in Fig. 1, A1-A5. The classified periods are also identified in Fig. 2, combined with the coloured columns to indicate the precipitation rate and local wind direction. 


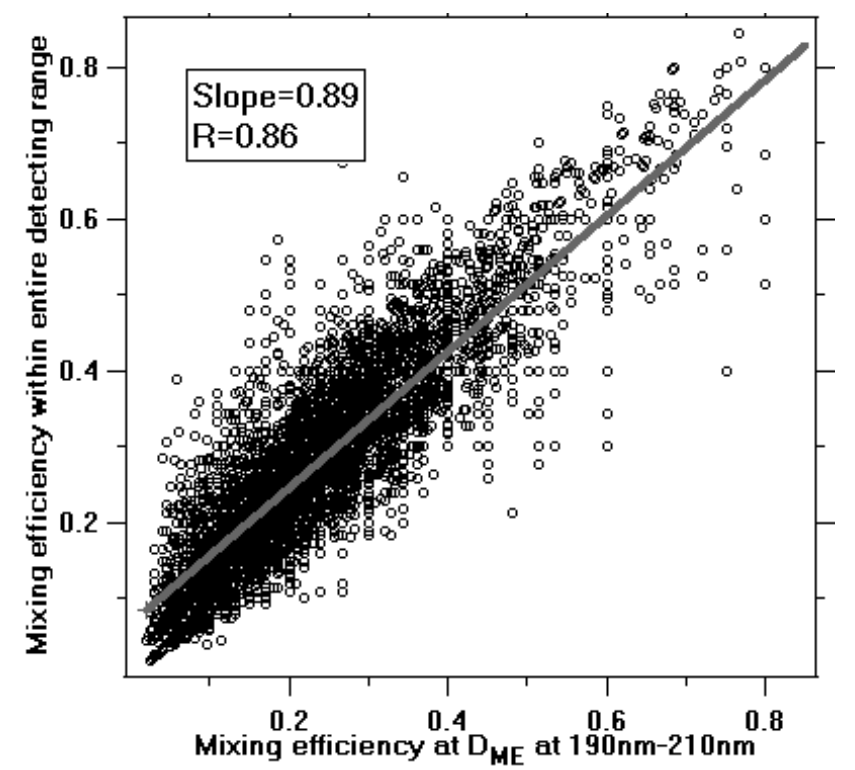

Fig. 5. The relationship between BC mixing efficiency over the entire size range of the SP2 and at the median diameter (190-210 nm).

The first two periods, from 26th February to the 4th March, were relatively clean, this is reflected in the low concentrations of $\mathrm{CN}$ and absorbing rBC, as shown in Fig. 2, Fig. 6a and detailed in Table 2. All these days belonged to the weather class AW, where aerosol concentrations are typically below average during this time of the year (Lugauer et al., 1988). During most of this period, the air masses originated in the free troposphere over the North Atlantic Ocean, with rapid transport across north Western Europe and descent to the Jungfraujoch. It is possible that on some occasions during this period polluted air from the industrialized parts of Western Europe was transported to the site. There is evidence of frontal passage early in this period. The dominant local horizontal wind direction was northerly $(\mathrm{N})$. A sharp enhancement of $\mathrm{rBC}$ concentration was observed when the local wind was a southeasterly (SE) direction. This is consistent with the known regional sources in the densely populated and highly industrialized Po Valley, north Italy. As Seibert et al. (1998) showed, there can be significant advection of the pollutants in the Po Valley to the northwest high alpine region. Reimann et al. (2008) analyzed 7 years of continuous observations of halocarbons at Jungfraujoch and concluded that a strong influence on the halocarbon levels was found from the Po Valley. In addition, it should be also noted that during this period, the site received continuous heavy snow fall (Fig. 2), when a large proportion of aerosols were removed. Back trajectory analyses showed that precipitation occurred throughout the previous $3 \mathrm{~d}$ during the period from 26th to 27th February, whereas from 28th February to 4th March the precipitation was more likely to be localised.

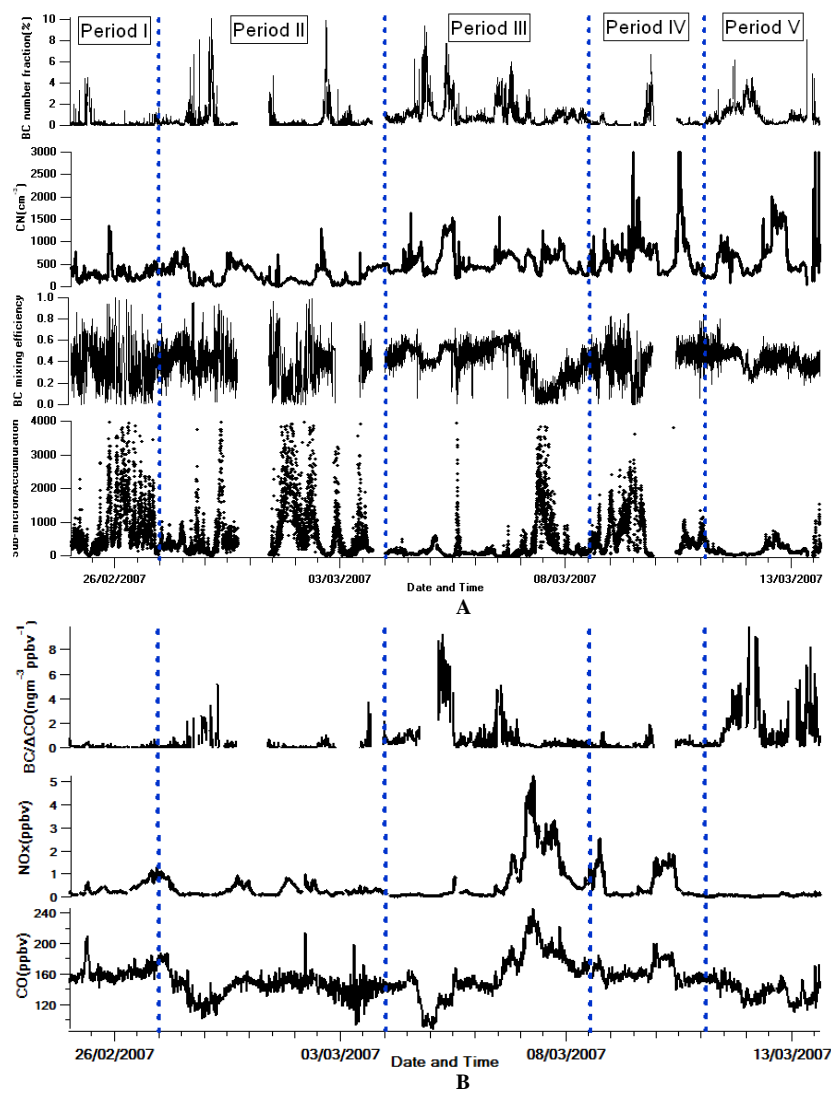

Fig. 6. (A) Time series of aerosol properties during the entire experiment with the classified periods separated by dotted lines, from bottom to top: numerical ratio of sub-micron/accumulation mode particles as measured by the SP2; $\mathrm{BC}$ mixing efficiency; $\mathrm{CN}$ concentration measured by the $\mathrm{CPC}$; $\mathrm{rBC}$ number fraction within the population of sub-micron aerosols. (B) Time series of trace gases, from bottom to top: $\mathrm{NO}_{\mathrm{x}}$ volume mixing ratio (ppbv); $\mathrm{CO}$ volume mixing ratio (ppbv); $\mathrm{BC} / \Delta \mathrm{CO}\left(\mathrm{ng} \mathrm{m}^{-3} \mathrm{ppbv}^{-1}\right)$.

In contrast, convective or mixed type weather types were present during the periods III, IV, and V, indicating the importance of vertical motion during the remainder of the campaign. On the days preceding the 5th March (Period III) the air masses had passed over Spain and southeastern France prior to arrival at the Jungfraujoch. Wet deposition is of less importance for the particle removal during this phase, as shown in Fig. 2, and rBC mass loading reached its maximum during the experiment. The consistent finding was the rBC mass increase always coincided with SE local wind, and the mass loading was low when the local wind was from the $\mathrm{N}$ bringing air to the site from the plateau.

The measurements conducted on 7th March provided evidence that this site can also be a recipient of relatively fresh pollutants. As shown by Fig. $6 \mathrm{~b}$, both $\mathrm{NO}_{\mathrm{x}}$ and $\mathrm{CO}$ concentrations were significantly elevated, with $\mathrm{NO}_{\mathrm{x}}$ increasing by up to five times its mean value. Figure $6 a$ shows that during this period the observed $\mathrm{BC}$ was poorly mixed (low $\mathrm{BC}$ mixing efficiency) and a large number of Aitken mode 
Table 2. A summary of meteorological conditions and aerosol properties categorized by five periods classified by back trajectory analysis (Fig. 1, A1-A5). The mean and standard deviations are shown for each parameter and the number in brackets is median value.

\begin{tabular}{|c|c|c|c|c|c|}
\hline $\begin{array}{l}\text { Periods classified } \\
\text { by back } \\
\text { trajectories }\end{array}$ & Period I & Period II & Period III & Period IV & Period V \\
\hline Date & $26 \mathrm{Feb}-27 \mathrm{Feb}$ & 28 Feb-4 Mar & 5 Mar-8 Mar & 9 Mar-11 Mar & 12 Mar-13 Mar \\
\hline \multicolumn{6}{|l|}{$\begin{array}{l}\text { Meteorological } \\
\text { conditions }\end{array}$} \\
\hline $\begin{array}{l}\text { Relative Humidity } \\
\text { (RH) }\end{array}$ & $96.7 \pm 5.9$ & $92.7 \pm 8.84$ & $62.7 \pm 32.0$ & $53.2 \pm 35.1$ & $49.3 \pm 22.8$ \\
\hline $\begin{array}{l}\text { Ambient tem- } \\
\text { perature }\left({ }^{\circ} \mathrm{C}\right)\end{array}$ & $-13.8 \pm 1.8$ & $-10.0 \pm 3.0$ & $-9.8 \pm 2.4$ & $-13.1 \pm 2.0$ & $-9.3 \pm 1.5$ \\
\hline Precipitation type & Heavy snow & Heavy snow & Weak snow & Heavy snow + medium snow & Weak snow \\
\hline $\begin{array}{l}\text { Local horizontal } \\
\text { wind direction }\end{array}$ & $\mathrm{SE}+\mathrm{N}$ & $\mathrm{N}$ & SE & $\mathrm{N}$ & SE \\
\hline $\begin{array}{l}\text { Local horizontal } \\
\text { wind speed }(\mathrm{m} / \mathrm{s})\end{array}$ & $5.6 \pm 2.8$ & $6.4 \pm 3.1$ & $5.4 \pm 3.7$ & $4.7 \pm 1.9$ & $8.8 \pm 4.1$ \\
\hline \multicolumn{6}{|l|}{$\begin{array}{l}\text { Aerosol based } \\
\text { properties } \\
\text { (median value) }\end{array}$} \\
\hline $\begin{array}{l}\mathrm{rBC} \text { mass } \\
\text { loading }\left(\mathrm{ng} \mathrm{m}^{-3}\right)\end{array}$ & $4.4 \pm 5.0(2.25)$ & $3.8 \pm 4.6(1.4)$ & $30.9 \pm 20.7(20.5)$ & $11.1 \pm 10.5(7.0)$ & $32.9 \pm 20.5(19.4)$ \\
\hline $\begin{array}{l}\mathrm{rBC} \text { number } \\
\text { fraction }\end{array}$ & $0.20 \pm 0.45$ & $0.45 \pm 1.0$ & $1.15 \pm 1.16$ & $0.33 \pm 0.62$ & $1.04 \pm 0.90$ \\
\hline $\begin{array}{l}\text { BC mixing } \\
\text { efficiency }\end{array}$ & $0.37 \pm 0.16$ & $0.42 \pm 0.14$ & $0.41 \pm 0.17$ & $0.42 \pm 0.14$ & $0.42 \pm 0.09$ \\
\hline $\begin{array}{l}\text { Sub-micron } \\
\text { particles }\left(\mathrm{cm}^{-3}\right)\end{array}$ & $300 \pm 182(252)$ & $256 \pm 188(201)$ & $554 \pm 255(464)$ & $693 \pm 434(636)$ & $673 \pm 581(505)$ \\
\hline $\begin{array}{l}\text { Sub-micron/ } \\
\text { Accumulation } \\
\text { mode ratio }\end{array}$ & $2045 \pm 1914(1275)$ & $1401 \pm 1731(783)$ & $641 \pm 1217(254)$ & $1431 \pm 1302(1018)$ & $445 \pm 387(311)$ \\
\hline
\end{tabular}

particles (high sub-micron/accumulation mode ratio) were present. The back trajectory analysis on 7 th March revealed that the air mass was advected from lower altitudes. The presence of $\mathrm{NO}_{\mathrm{x}}$ suggested that the air mass was relatively fresh and the emissions were most likely to have occurred in the past day. More tellingly, a fresh plume was clearly observed around 12:00 noon on 7th March. Around this time, the BC mixing efficiency was low, and this was associated with a significant increase in the concentration of $\mathrm{NO}_{\mathrm{x}}$ and $\mathrm{CO}$, and enhancement of the loading of smaller particles.

The synoptic flow brought air to the site from the north during period IV from 09 March to 10 March, with the flow mainly from mid-west Germany and above the Swiss plateau. SE local winds were rarely observed during this period. A few periods of enhanced $\mathrm{rBC}$ were detected, possibly associated with the convective weather type, but the overall contribution of $\mathrm{rBC}$ was small. However, during this period a substantial number of sub-micron particles were observed, resulting in a decreased $\mathrm{rBC}$ number fraction (Fig. 6a). The sporadic peaks of $\mathrm{rBC}$ loading coincided with pulses of $\mathrm{NO}_{\mathrm{x}}$ (Fig. 6b). These periods were also associated with low BC mixing efficiency and enhanced Aitken mode particles, which implied more localized pollutants arising from sources on the Swiss plateau (even though the largest peaks in $\mathrm{CN}$ did not coincide with the rBC peaks). 
The air mass history during period V (11 March-13 March) essentially contrasted with the previous days, when the air was transported over southern-eastern Europe. The strong easterly flow brought persistently pollutants from eastern Europe. The back-trajectories indicated descending air masses (Fig. 1, A1-A5). The weather classification yielded a convective weather type with subsidence, which provides the best situation for thermally driven convection. This is also confirmed by the fact that the increase in the rBC concentration started around noon on 11 March and 12 March. The rBC in this period showed a high degree of internal mixing, with low $\mathrm{NO}_{\mathrm{x}}$ levels and only a small proportion of submicron particles were observed to be in the Aitken mode. This may be regarded as an indication that these $\mathrm{rBC}$ particles had experienced long distance transport before arriving at the site.

\subsection{The free tropospheric background under the influences of ground sources and wet removal}

The air mass history along with the aerosol and trace gas measurements indicates a typical free tropospheric background at this site for most of the experimental periods, when $\mathrm{NO}_{\mathrm{x}}$ and $\mathrm{CO}$ concentrations were not enhanced, $\mathrm{rBC}$ mass loadings showed little variation. The measured results in the free tropospheric background are analyzed as observed occurrence and presented in the first row of Fig. 7. However, pollutants in the background air can be influenced by valley sources as the SE winds can vent anthropogenic pollutants from the southern Alpine area and industrial northern Italy. The convective weather type could also lift the boundary air from northward when influenced by $\mathrm{N}$ wind (Fig. 2), however, the pollution sources from this direction were less intense and more infrequent. During transport, aerosols are processed, being scavenged, and subsequently removed by wet deposition in the form of precipitation. The particles incorporated into clouds that had not precipitated were also collected by the inlet system. The SE wind direction and precipitation rate therefore govern any perturbation to the measured aerosol loadings in the tropospheric background at this site. These conditions have been identified and the frequency distributions of a range of aerosols and gas phase parameters under these situations are shown in Fig. 7.

Under the influence of SE wind, enhanced rBC mass loadings were frequently observed to perturb the background (Fig. 7a) from $13 \pm 5 \mathrm{ng} \mathrm{m}^{-3}$ to $34 \pm 14 \mathrm{ng} \mathrm{m}^{-3}$ (Table 2). A median value $18 \mathrm{ng} \mathrm{m}^{-3}$ of BC mass loading from Jungfraujoch site for winter conditions was reported by Petzold et al. (2007), which falls within the results in this study. However, the results are lower than the long term averaged $\mathrm{BC}$ mass measurements reported by Cozic et al. (2007) during the winter time in 2004 and $2005\left(54.2 \mathrm{ng} \mathrm{m}^{-3}\right)$, which may result from the different techniques for the quantification of $\mathrm{BC}$ mass, although it may also be due to that the site experienced fewer strong pollution events during this study. The
$\mathrm{rBC}$ mass concentration in the tropospheric background observed in this study is also comparable with the values reported by Schwarz et al. (2006) in the Northern mid-latitude troposphere (1-10 $\left.\mathrm{ng} \mathrm{m}^{-3}\right)$. Under SE local wind conditions, substantial amounts of pollutants were observed from more localized pollution sources, such as industrial northern Italy. The importance of vertical transport at the Jungfraujoch was first observed by Baltensperger et al. (1991), and has been analysed in detail by Lugauer et al. (1998, 2000). In addition to transport pathways, precipitation had a significant impact on the removal of $\mathrm{rBC}$, reducing the average $\mathrm{rBC}$ mass loading to $4 \pm 2 \mathrm{ng} \mathrm{m}^{-3}$ when precipitation particles were over $200 \mathrm{~L}^{-1}$. On average, about $65 \%$ of $\mathrm{rBC}$ mass was removed by precipitation compared with the tropospheric background when precipitation was not observed at the site (Fig. 7a; Table 2). The mass fraction of $\mathrm{rBC}$ was also calculated by dividing the $\mathrm{rBC}$ mass loading with SMPS-determined total aerosol mass assuming an average aerosol density of $1.5 \mathrm{~g} \mathrm{~cm}^{-3}$ using the method of Cozic et al. (2008b). The calculated $\mathrm{rBC}$ mass fraction has only a weak dependence on SE wind or precipitation, ranging from $0.01-0.07$ during this experiment, which agrees with the out-of-cloud results of BC reported by Cozic et al. (2008b).

Both $\mathrm{CO}$ and $\mathrm{BC}$ can act as tracers of primary pollutants because their sources are similar, though their emission ratio is highly dependent on the sources and combustion conditions (Bond et al., 2004), as well as controlled by meteorological conditions. This tropospheric background maintained a stable median $\mathrm{CO}$ concentration of $150 \mathrm{ppbv}$ (Fig. 7b), but was elevated frequently when influenced by SE wind, corresponding to periods of enhanced $\mathrm{rBC}$ mass. The loading of $\mathrm{CO}$ in the troposphere was not largely affected by precipitation removal unlike BC. The lower peak occurrence of $\mathrm{CO}$ concentration $(\sim 120 \mathrm{ppb})$ in the frequency distributions is consistently observed under different conditions. This is considered to represent the background value and has been subtracted from the measured $\mathrm{CO}$ concentration to derive $\mathrm{BC} / \triangle \mathrm{CO}$ ratios, as depicted in Fig. 7c. A strong correlation between $\mathrm{BC}$ and $\mathrm{CO}$ has been observed during ground based experiments under the urban environments (e.g. Baumgardner et al., 2002; Kondo et al., 2006), whereas the BC exhibits less dependence on the $\mathrm{CO}$ concentration when away from the sources and the $\mathrm{BC} / \mathrm{CO}$ ratio reduces (Spackman et al., 2008). These trends are consistently observed during this study. A strong correlation between $\mathrm{CO}$ and $\mathrm{BC}$ was observed at this site only when it was influenced by SE wind, and the average $\mathrm{BC} / \Delta \mathrm{CO}$ ratio $\left(1.5 \mathrm{ng} \mathrm{m}^{-3} \mathrm{ppbv}^{-1}\right.$, Table 3) falls within the other ground based studies (0.88$6.3 \mathrm{ng} \mathrm{m}^{-3} \mathrm{ppbv}^{-1}$, references above), indicating a strong influence by ground sources. However in the tropospheric background, there is a larger variation in $\mathrm{CO}$ for little change in background $\mathrm{BC}$ (Fig. 6), leading to the reduced $\mathrm{BC} / \triangle \mathrm{CO}$ ratios (average $0.5 \mathrm{ng} \mathrm{m}^{-3} \mathrm{ppbv}^{-1}$, Table 3), and this ratio is further reduced during periods when the air masses reaching the site have been influenced by significant precipitation 


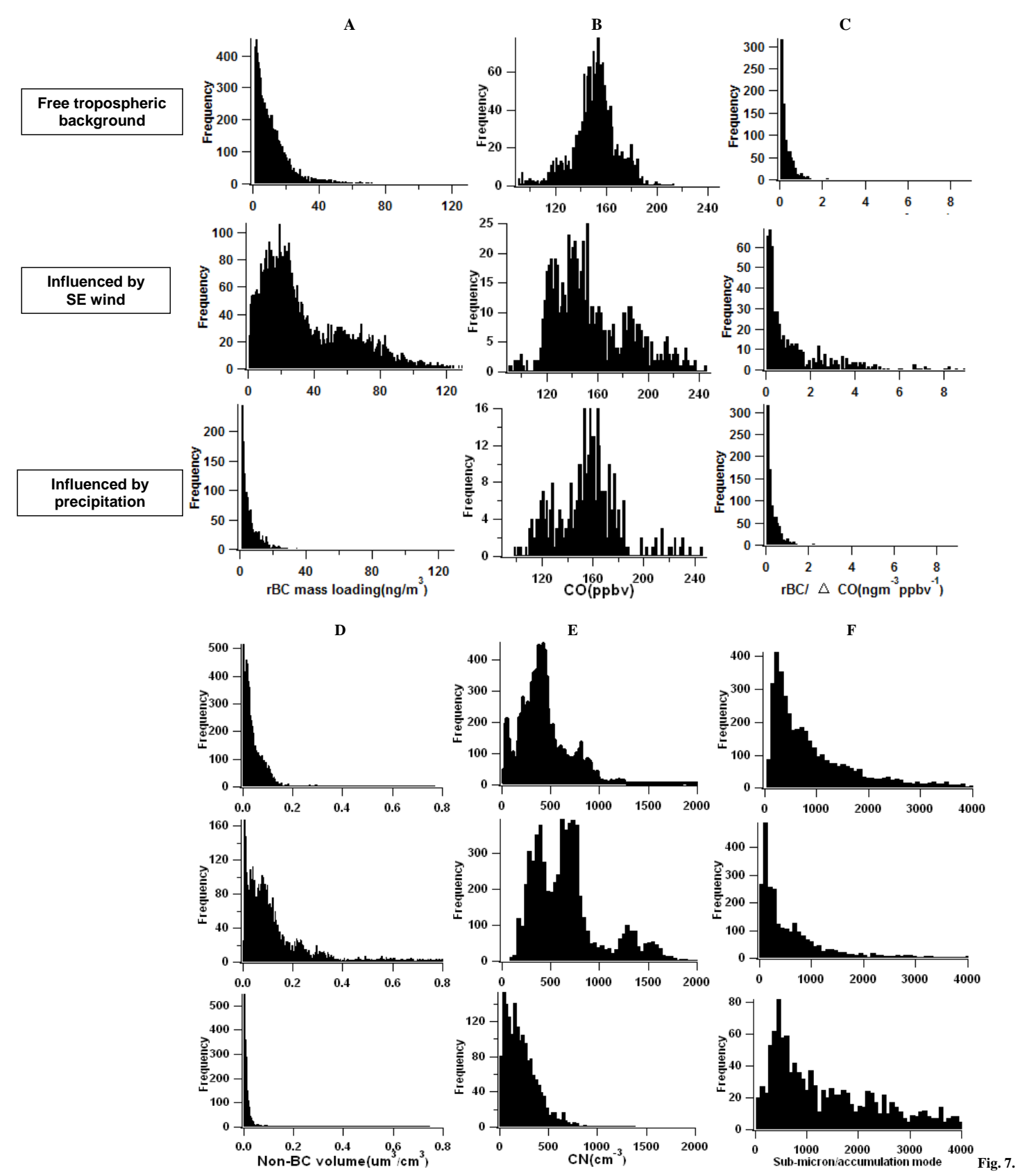

Fig. 7. Frequency distributions of aerosol and trace gas properties under free tropospheric background conditions (top row), under the influence of SE winds (middle row), and when influenced by precipitation (bottom row): column (A) rBC mass loading; column (B) $\mathrm{CO}$ concentration; (C) $\mathrm{BC} / \Delta \mathrm{CO}$ ratio; (D) volume of non-BC particles (200-720nm); (E) $\mathrm{CN}$ concentration; (F) number ratio of sub-micron/accumulation mode.

$\left(0.24 \mathrm{ng} \mathrm{m}^{-3} \mathrm{ppbv}^{-1}\right)$. This is due to the different atmospheric removal mechanisms of $\mathrm{CO}$ and $\mathrm{BC}$. The lifetime of $\mathrm{CO}$ in the atmosphere is principally controlled by oxidation via $\mathrm{OH}$ and is around 3 months (Holloway et al., 2000), whereas the atmospheric lifetime of $\mathrm{BC}$ is in the order of 5$10 \mathrm{~d}$ with the sink dominated by wet deposition (Textor et al., 2006).
The loading of non-BC aerosols in the accumulation mode as optically sized by the SP2 $(200-720 \mathrm{~nm})$ is shown in Fig. 7d. This shows a significant enhancement of accumulation mode particles in SE wind direction, and about $78 \%$ of the total volume was removed by precipitation compared with the tropospheric background (Table 3). Periods of SE wind and precipitation influenced the $\mathrm{CN}$ concentration (down to $10 \mathrm{~nm}$ ) in similar ways (Fig. 7e). Accumulation 
Table 3. A summary of the data presented in Fig. 7, including the median value, mean value and 10\%, 25\%, $75 \%$, $90 \%$ percentiles for each property.

\begin{tabular}{|c|c|c|c|c|c|c|c|c|c|c|c|c|c|c|c|c|c|c|c|c|}
\hline & \multicolumn{7}{|c|}{$\mathrm{rBC}$ mass loading $\left(\mathrm{ngm}^{3}\right)$} & \multicolumn{7}{|c|}{$\mathrm{CO}(\mathrm{ppbv})$} & \multicolumn{6}{|c|}{$\mathrm{rBC} / \Delta \mathrm{CO}\left(\mathrm{ng} \mathrm{m}^{-3} \mathrm{ppbv}^{-1}\right)$} \\
\hline Percentiles & $10 \%$ & $25 \%$ & $50 \%$ & $75 \%$ & 90 & & Mear & $10 \%$ & 25 & & $50 \%$ & $75 \%$ & $90 \%$ & Mean & $10 \%$ & $25 \%$ & $50 \%$ & $75 \%$ & $90 \%$ & Mean \\
\hline $\begin{array}{l}\text { Free tropo- } \\
\text { spheric background }\end{array}$ & 0.62 & 3.12 & 8.11 & 15.59 & 27. & & 13.2 & 126.2 & 14 & & 149.5 & 158.1 & 170.4 & 149.9 & 0.01 & 0.09 & 0.2 & 0.5 & 0.8 & 0.5 \\
\hline $\begin{array}{l}\text { Influenced by } \\
\text { SE wind }\end{array}$ & 6.17 & 12.97 & 24.08 & 50.63 & 74 & & 34.28 & 119.3 & 12 & & 144.7 & 173.1 & 195.3 & 153.7 & 0.03 & 0.1 & 0.7 & 2.2 & 3.8 & 1.5 \\
\hline \multirow{2}{*}{$\begin{array}{l}\text { Influenced by } \\
\text { precipitation }\end{array}$} & 0.45 & 0.89 & 2.68 & 7.15 & 14 & & 6.23 & 118.5 & 13 & & 154.1 & 164.4 & 177.8 & 154.2 & 0.01 & 0.05 & 0.1 & 0.2 & 0.6 & 0.24 \\
\hline & \multicolumn{7}{|c|}{ Non-BC volume $\left(\mu \mathrm{m}^{3} / \mathrm{cm}^{3}\right)$} & & \multicolumn{6}{|c|}{$\mathrm{CN}\left(\mathrm{cm}^{-3}\right)$} & \multicolumn{6}{|c|}{ Sub-micron/Accumulation mode ratio } \\
\hline Percentiles & $10 \%$ & $25 \%$ & $50 \%$ & $75 c$ & & $90 \%$ & & Mean & $10 \%$ & $25 \%$ & $50 \%$ & $75 \%$ & $90 \%$ & Mean & $10 \%$ & $25 \%$ & $50 \%$ & $75 \%$ & $90 \%$ & Mean \\
\hline $\begin{array}{l}\text { Free tropo- } \\
\text { spheric background }\end{array}$ & 0.0575 & 0.0128 & 0.0286 & 0.07 & & 0.118 & & 0.0523 & 119 & 248 & 377 & 539 & 813 & 454 & 120 & 200 & 597 & 1392 & 2822 & 1177 \\
\hline $\begin{array}{l}\text { Influenced by } \\
\text { SE wind }\end{array}$ & 0.0135 & 0.0433 & 0.0993 & 0.17 & & 0.346 & & 0.1541 & 230 & 341 & 564 & 712 & 1232 & 669 & 11 & 83 & 248 & 800 & 1747 & 746 \\
\hline $\begin{array}{l}\text { Influenced by } \\
\text { precipitation }\end{array}$ & 0.0006 & 0.0009 & 0.0031 & 0.01 & & 0.033 & & 0.0168 & 6 & 61 & 144 & 281 & 419 & 214 & 262 & 420 & 1205 & 2462 & 4346 & 1847 \\
\hline
\end{tabular}

mode aerosols principally contain secondary species arising via condensation and coagulation processes (Raes et al., 2000), whereas anthropogenic primary aerosols are produced predominantly as Aitken mode particles (e.g. Kittelson et al., 2004). Therefore the relative fraction of accumulation mode particles can be an indicator of particle ageing time. As Fig. $7 \mathrm{f}$ shows, a relatively large fraction of accumulation mode particles were observed in SE wind direction, indicating that the aerosols transported to this site had been well aged. The aerosol present during periods when air masses were affected by precipitation were biased towards smaller sizes compared to the average particle distribution for the period, suggesting the larger aerosols are preferentially removed by scavenging of precipitation (Henning et al., 2002).

\subsection{The size distribution and mixing state of $\mathrm{BC}$}

The constructed lognormal size distributions of $\mathrm{rBC}$ show no significant difference under free tropospheric conditions, when influenced by SE wind and precipitation (Fig. 8a). The geometric mean MED $\left(D_{\mathrm{gm}}\right)$ from directly measured size distribution (190-720 nm) is also calculated in Fig. 8b. The $D_{\text {gm }}$ consistently peaks at $220-240 \mathrm{~nm}$ for different conditions, but shows slightly higher occurrence at larger sizes when this site is influenced by SE wind, indicating that within the detectable size range, the particles with a larger $\mathrm{rBC}$ core have a more efficient removal compared to the particles with a small $\mathrm{rBC}$ core. This result suggests the overall wet removal of $\mathrm{BC}$ is highly independent of the core size, and the different sizes of $\mathrm{rBC}$ could have been scavenged following different mechanisms, i.e. nucleation scavenging by cloud particles to form precipitation, or impaction scavenging by dissolving into the precipitation particle or aerosolhydrometeor coagulation (Jacobson, 2004).
As discussed above, the $\mathrm{BC}$ that contains an absorbing core with a mass fraction less than $27 \%$ is considered to be thickly coated, and the mixing efficiency (ME) indicates the number fraction of thickly coated BC. As Fig. 9a shows, about $40 \pm 15 \%$ of the $\mathrm{BC}$ is thickly coated during periods of tropospheric background, agreeing with data from the tropical troposphere (Schwarz et al., 2008a). During SE winds, the ME increased to $48 \pm 17 \%$, but also contained a considerable fraction of fresher $\mathrm{BC}$ with $\mathrm{ME}$ lower than 0.23 . The $\mathrm{BC}$ with low ME largely correlated to the enhancement of $\mathrm{NO}_{\mathrm{x}}$ concentration (Fig. 9b). As the $\mathrm{NO}_{\mathrm{x}}$ has a relatively shorter atmospheric lifetime and is more likely to be a marker of fresher sources, this corresponds to the result in Fig. 9b, indicating that the lower ME values are associated with more recently formed BC. Solid fuel fuel combustion (wood) is the primary source of home heating in central Switzerland (e.g. Alfarra et al., 2007; Targino et al., 2009) or from the Po valley when the meteorological conditions make transit times from northern Italy short (Forrer et al., 2000). Such sources are considerably closer to the site compared to regionally transported sources. Hence $\mathrm{NO}_{\mathrm{x}}$ concentrations have not yet reduced nor have $\mathrm{BC}$ particles become extensively coated. However, the source attribution in this study is not conclusive. The $\mathrm{BC}$ remaining at the background after precipitation removal exhibited a slight lower ME $(0.36 \pm 0.14)$, which could be explained by the enhanced scavenging of coated $\mathrm{BC}$ particles.

Figure 10 shows that throughout the experiment, increased numbers of accumulation mode particles are associated with periods when $\mathrm{BC}$ is more highly mixed. The conversion from Aitken mode to accumulation mode may be driven by self-coagulation of primary aerosols under high loadings or through condensation of volatile or semi-volatile materials onto solid/liquid aerosol surfaces (Raes et al., 2000). 


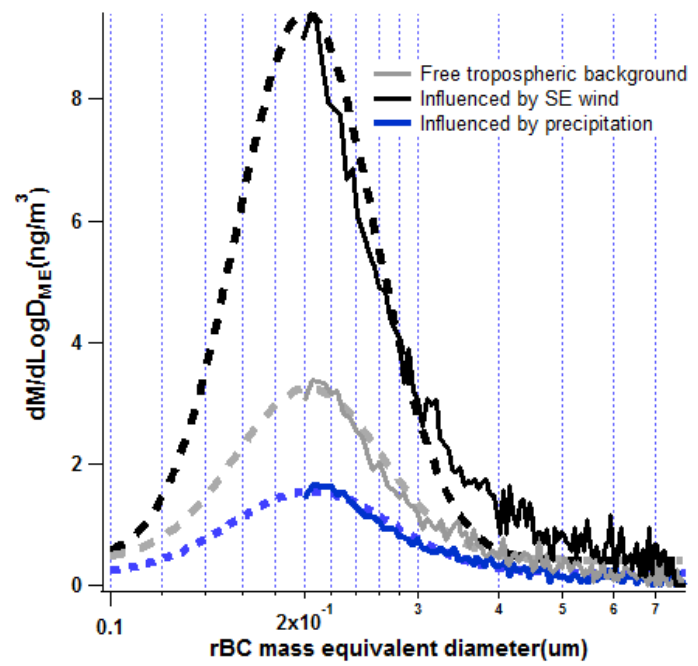

A

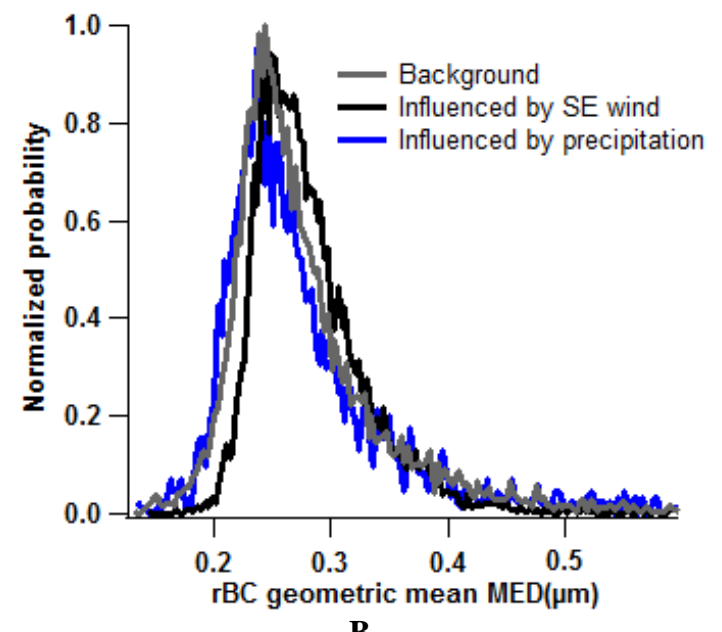

B

Fig. 8. (A) Mean rBC mass size distribution measured (solid lines) under different conditions. The dotted lines show the lognormal fittings on the measured size distributions to derive the total mass loadings. (B) The occurrence frequencies of geometric mean MED for $\mathrm{rBC}$ core under different conditions.

The coagulation process is of minor importance at ambient aerosol concentrations away from particle sources (Jacobson, 2002), hence it is likely that the condensation drives the growth of Aitken mode aerosols. This includes the condensation onto BC surfaces, making them more internally mixed. Further evidence for condensation driving the transformation of $\mathrm{BC}$ in the free troposphere in the northern hemisphere is provided from the statistical analysis of Schröder et al. (2002), and also by Moteki et al. (2007). Particles in the accumulation mode are more efficiently removed compared to particles in the Aitken mode. This can be seen in Fig. 10, the large circles denoting increased precipitation are increased to the right hand side of the plot, indicating a reduced population of accumulation mode particles under these conditions.

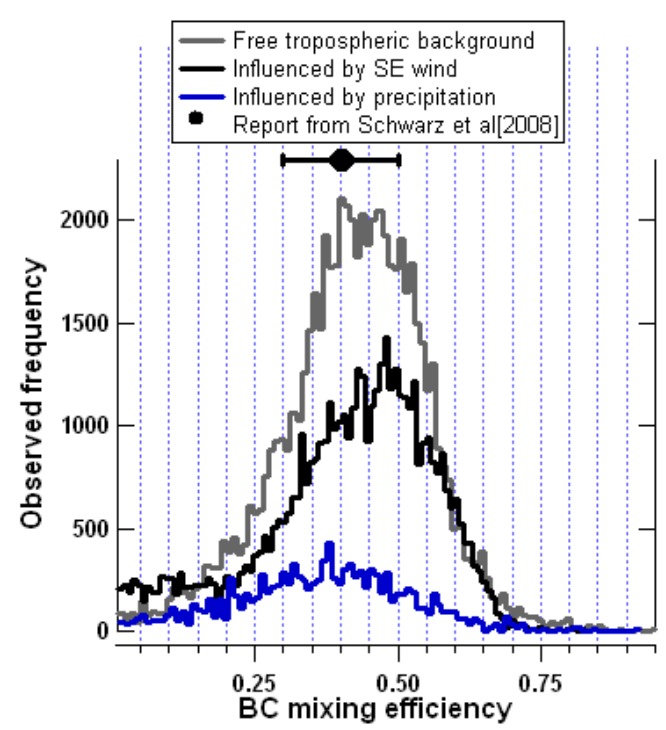

A

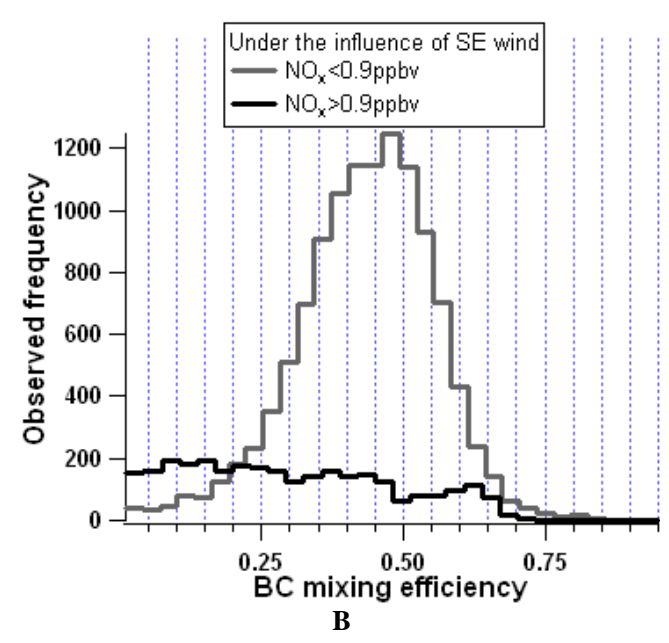

Fig. 9. (A) The frequency distribution of BC mixing efficiency under different conditions as categorized in Fig. 7. The range of values reported by Schwarz et al. (2008a) from the northern tropic troposphere is indicated. (B) The BC mixing efficiency under the influence of SE wind, as categorized by different levels of $\mathrm{NO}_{\mathrm{x}}$ concentration.

\section{Summary}

This paper presents data of continuous aerosol microphysical measurements at the Jungfraujoch Research Station, a mountain site in the Swiss Alps, during the late winter season of 2007. The main thrust of this study was to characterize the black carbon mass, size distribution and mixing state in sub-micron aerosols using a single particle incandescence method. Air masses arriving at the JFJ were classified using back trajectory analysis and air mass characterisation, in addition to the measurements of $\mathrm{rBC}, \mathrm{CN}$ and trace gases. It is the first time that the physical properties of $\mathrm{BC}$, including the particle size, total mass loading and mixing state, have 


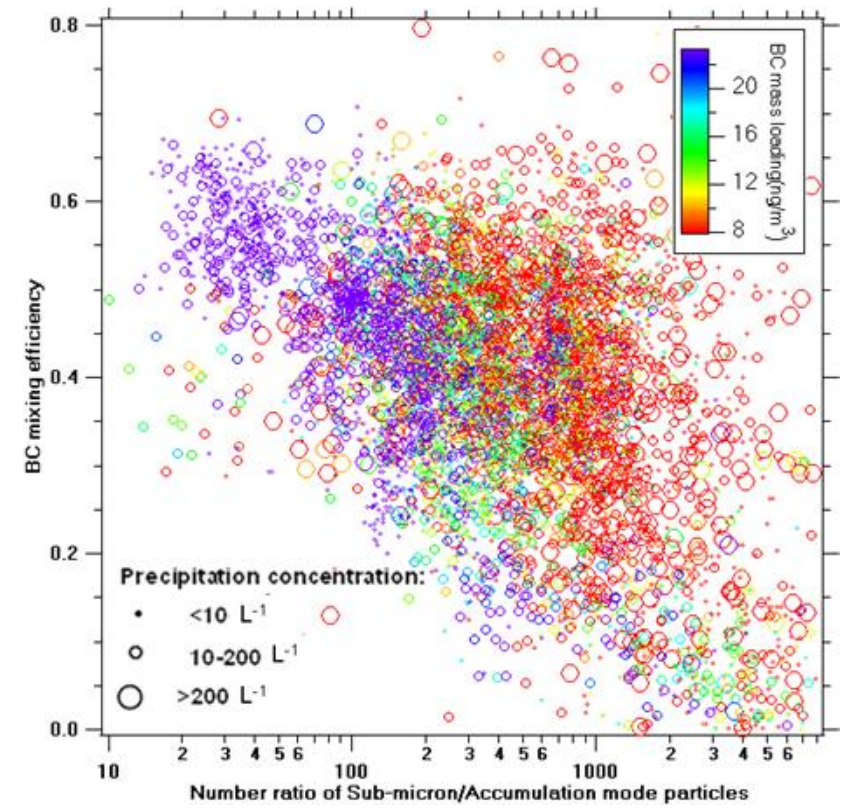

Fig. 10. BC mixing efficiency as a function of the ratio between sub-micron and accumulation mode aerosol number, colored by rBC mass loading. The size of the markers denotes the intensity of precipitation.

been investigated in the free troposphere above Europe using a single particle approach. A median mass absorption coefficient (MAC) of $10.2 \pm 3.2 \mathrm{~m}^{2} \mathrm{~g}^{-1}$ at $\lambda=630 \mathrm{~nm}$ was derived by comparing single particle incandescence measurements of black carbon mass with continuous measurements of absorption coefficient. This value is comparable with other estimates at this location. The weather type (advective, convective, or mixed) was shown to have a strong influence on the vertical transport. Southeasterly winds (SE) associated with mixed or convective weather types were observed to have the potential to vent boundary layer air that is impacted from pollution sources. These sources could be influenced by the southern Alpine area and industrial northern Italy. The pollutants at this site were also subjected to considerable influence by precipitation removal. A statistical analysis has been applied over the data from the entire experimental period to classify the observation period into different representative types of circulation patterns, weather types and precipitation regimes, namely the free tropospheric background; periods of SE wind; and periods of significant precipitation scavenging. The free tropospheric background is categorized as free of significant precipitation, lack of $\mathrm{NO}_{\mathrm{x}}$ and $\mathrm{CO}$ enhancement, during these periods the $\mathrm{rBC}$ mass loading, accumulation mode particle concentration and $\mathrm{CN}$ displayed relatively low variation. The SE wind conditions were largely associated with enhanced concentrations of rBC mass, increasing to $180 \%$ of the experiment average, during which rBC mass was observed to be highly correlated with CO concentration. This suggests strong sources originating from in-

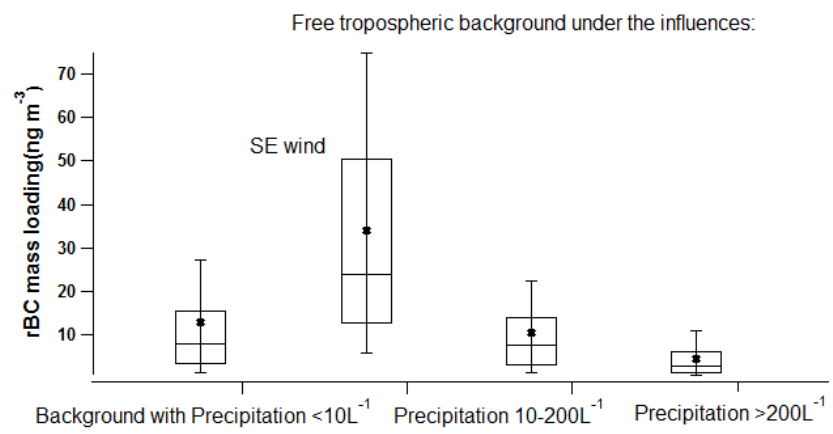

Fig. 11. Statistical analysis of the rBC mass loading at this site: The free tropospheric background contributed by ground sources delivered to the JFJ during periods of SE wind ad the sink governed by precipitation. The upper and lower edges of the box denote the $25 \%$ and $75 \%$ percentiles respectively. The lines in the middle of box and cross markers indicate the median and average values, with error bars explaining the $10 \%$ and $90 \%$ percentiles.

complete combustion. This observation indicates the importance of surface sources to the burden in the free tropospheric air. Precipitation removed about $65 \%$ of the $\mathrm{rBC}$ mass from the free tropospheric background reducing the mean loading from $13 \pm 5 \mathrm{ng} \mathrm{m}^{-3}$ to $6 \pm 2 \mathrm{ng} \mathrm{m}^{-3}$, and as CO concentration was not largely affected by wet removal, the $\mathrm{CO} / \mathrm{BC}$ increased in these conditions. Particles in the accumulation mode were observed to be preferentially removed by precipitation compared to smaller particles in the Aitken mode. Figure 11 summarizes the differences in $\mathrm{rBC}$ mass loading in SE winds compared to the free tropospheric background and also compared to the periods of increased precipitation. The background loading is of the same order as has been reported from other tropospheric background stations in northern midlatitudes (e.g. Schwarz et al., 2006).

The size distribution of $\mathrm{rBC}$ during valley flows or during periods of wet removal did not vary significantly from the free tropospheric background, indicating that the ageing and sink of $\mathrm{BC}$ are highly independent of the core size. A method to examine the mixing state of $\mathrm{BC}$ has been demonstrated - particles with an absorbing core that have mass fractions of less than $27 \%$ are considered to be thickly coated. About $40 \pm 15 \%$ of the observed BC was thickly coated during the periods when the site experienced free tropospheric background conditions. When SE winds vented air mass from southern Alpine valleys, the $\mathrm{BC}$ mixing state was more variable. Though the majority of $\mathrm{BC}$ particles were thickly coated $(48 \pm 17 \%)$ a fraction of relatively fresh BC coexisted and was largely correlated to the enhancement in $\mathrm{NO}_{\mathrm{x}}$ concentration. The relative abundance of accumulation mode particles is correlated with the degree of $\mathrm{BC}$ mixing, suggesting the important role of condensable materials in increasing particle size as well as enhancing BC mixing state. It is likely that these volatile or semi-volatile condensable materials could contain a considerable fraction of 
secondary organic and sulfate at this site during the wintertime (Choularton et al., 2008; Sjogren et al., 2008).

$\mathrm{BC}$ transportation to the free troposphere is of great importance because of its potential ability to act as ice nuclei, hereafter reducing the lifetime of ice clouds by enhancing precipitation via ice phase (Lohmann, 2002). BC has the potential to act as heterogeneous IN, though definitive evidence remains elusive (Kärcher et al., 2007). In addition, BC may be incorporated into the ice phase via $\mathrm{CCN}$ activation of $\mathrm{BC}$ that has been internally mixed with water soluble components as a result of the soluble coating, which can subsequently freeze at temperatures below $-35^{\circ} \mathrm{C}$ - homogenous ice nucleation. Targino et al. (2009) observed that conditions of elevated concentration of $\mathrm{BC}$ and other organic and inorganic species at JFJ during CLACE 3 and CLACE 4, conducted in the winters of 2004 and 2005, respectively, were accompanied by an increase in occurrence of glaciated periods. The results suggest that pollution enhancement correlated with ice clouds and gives an indication that an increase in anthropogenic emissions may trigger important changes in mixed phase cloud microphysics, such as crystal number, habit and size.

Cozic et al. (2007) inferred that there was a high degree of $\mathrm{BC}$ internal mixing at the JFJ by observing a similar nucleation scavenging efficiency of $\mathrm{BC}$ compared to other species, however they did not provide the directly measured values of mixing state. The findings from this study agree with those of Cozic et al. (2007) and show that during periods of precipitation, BC exhibited a slightly lower degree of mixing (36 $\pm 14 \%$ thickly coated), possibly implying an enhanced scavenging due to the mixing with volatile/semi-volatile materials. However, rather than nucleation scavenging, the inertial scavenging of $\mathrm{BC}$ could play a more significant role when incorporated into ice particles of cirrus (Baumgardner et al., 2008), and the impaction with hydrometeor may also be an important contributor to $\mathrm{BC}$ removal by precipitation (Jacobson, 2004). More work is necessary to investigate the role of particle inertia and different mechanisms for $\mathrm{BC}$ to be nucleation activated as IN. The removed $\mathrm{BC}$ will be deposited to the snow along with the precipitation reaching the surface. This process can darken the snow, accelerating the snow melting, reducing the surface albedo, in turn resulting in the earth system to receive more solar radiation (Hansen and Nazarenko, 2004; Ramanathan and Carmichael, 2008).

Acknowledgements. This work was funded by the Natural Environment Research Council, UK (grant number NER/A/S/2003/00541), supported by MeteoSwiss within the Swiss Global Atmosphere Watch Programme, the Swiss National Science Foundation, the EC project EUSAAR (European Supersites for Atmospheric Aerosol Research). The authors gratefully acknowledge the NOAA Air Resources Laboratory (ARL) for the provision of the HYSPLIT transport and dispersion model and the READY website used in this study. We thank the International Foundation High Alpine Research Station Jungfraujoch and Gornergrat (HFSJG), who made it possible for us to carry out our experiments at the High Alpine
Research Station Jungfraujoch.

Edited by: W. Birmili

\section{References}

Alfarra, M. R. and Prevot, A. S. H.: Identification of the mass spectral signature of organic aerosols from wood burning emissions, Environ. Sci. Technol., 41(16), 5770-5777, 2007.

Baltensperger, U., Gaggeler, H. W., Jost, D. T., Emmenegger, M., and Nageli, W.: Continuous background aerosol monitoring with the epiphaniometer, Atmos. Environ., 25, 629-634, 1991.

Baltensperger, U., Gäggeler, H. W., Jost, D. T., Lugauer, M., Schwikowski, M., Weingartner, E., and Seibert, P.: Aerosol climatology at the high-alpine site Jungfraujoch, Switzerland, J. Geophys. Res., 102, 19707-19715, 1997.

Baumgardner, D., Raga, G., Peralta, O., Rosas, I., Castro, T., Kuhlbusch, T., John, A., and Petzold, A.: Diagnosing black carbon trends in large urban areas using carbon monoxide measurements, J. Geophys. Res., 107(D21), 8342, doi:10.1029/2001JD000626, 2002.

Baumgardner, D., Kok, G. L., and Raga, G. B.: On the diurnal variability of particle properties related to light absorbing carbon in Mexico City, Atmos. Chem. Phys., 7, 2517-2526, doi:10.5194/acp-7-2517-2007, 2007.

Baumgardner, D., Subramanian, R., Twohy, C., Stith, J., and Kok, G.: Scavenging of black carbon by ice crystals over the northern Pacific, Geophys. Res. Lett., 35, L22815, doi:10.1029/2008GL035764, 2008.

Bond, T. C., Streets, D. G., Yarber, K. F., Nelson, S. M,. Woo, J.H., and Klimont, Z.: A technology-based global inventory of black and organic carbon emissions from combustion, J. Geophys. Res., 109, D14203, doi:10.1029/2003JD003697, 2004.

Bond, T. C. and Bergstrom, R. W.: Light absorption by carbonaceous particles: An investigative review, Aerosol Sci. Technol., 40(1), 27-67, 2006.

Bond, T. C., Habib, G., and Bergstrom, R. W.: Limitations in the enhancement of visible light absorption due to mixing state, J. Geophys. Res., 111, D20211, doi:10.1029/2006JD007315, 2006.

Choularton, T. W., Bower, K. N., Weingartner, E., Crawford, I., Coe, H., Gallagher, M. W., Flynn, M., Crosier, J., Connolly, P., Targino, A., Alfarra, M. R., Baltensperger, U., Sjogren, S., Verheggen, B., Cozic, J., and Gysel, M.: The influence of small aerosol particles on the properties of water and ice clouds, Faraday Discuss., 137, 205-222, 2008.

Clarke, A. D., Shinozuka, Y., Kapustin, V. N., Howell, S., Huebert, B., Doherty, S., Anderson, T., Covert, D., Anderson, J., Hua, X., Moore, K. G., McNaughton, C., Carmichael, G., and Weber, R.: Size distributions and mixtures of dust and black carbon aerosol in Asian outflow: Physiochemistry and optical properties, J. Geophys. Res., 109, D15S09, doi:10.1029/2003JD004378, 2004

Collaud Coen, M. C., Weingartner, E., Nyeki, S., Cozic, J., Henning, S., Verheggen, B., Gehrig, R., and Baltensperger, U.: Long-term trend analysis of aerosol variables at the high alpine site Jungfraujoch, J. Geophys. Res., 112, D13213, doi:10.1029/2006JD007995, 2007.

Collaud Coen, M., Weingartner, E., Apituley, A., Ceburnis, D., Fierz-Schmidhauser, R., Flentje, H., Henzing, J. S., Jennings, S. G., Moerman, M., Petzold, A., Schmid, O., and Baltensperger, 
U.: Minimizing light absorption measurement artifacts of the Aethalometer: evaluation of five correction algorithms, Atmos. Meas. Tech., 3, 457-474, doi:10.5194/amt-3-457-2010, 2010.

Cozic, J., Verheggen, B., Mertes, S., Connolly, P., Bower, K., Petzold, A., Baltensperger, U., and Weingartner, E.: Scavenging of black carbon in mixed phase clouds at the high alpine site Jungfraujoch, Atmos. Chem. Phys., 7, 1797-1807, doi:10.5194/acp-7-1797-2007, 2007.

Cozic, J., Verheggen, B., Weingartner, E., Crosier, J., Bower, K. N., Flynn, M., Coe, H., Henning, S., Steinbacher, M., Henne, S., Collaud Coen, M., Petzold, A., and Baltensperger, U.: Chemical composition of free tropospheric aerosol for PM1 and coarse mode at the high alpine site Jungfraujoch, Atmos. Chem. Phys., 8, 407-423, doi:10.5194/acp-8-407-2008, 2008.

Cozic, J., Mertes, S., Verheggen, B., Cziczo, D. J., Gallavardin, S. J., Walter, S., Baltensperger, U., and Weingartner, E.: Black carbon enrichment in atmospheric ice particle residuals observed in lower tropospheric mixed phase clouds, J. Geophys. Res., 113, D15209, doi:10.1029/2007JD009266, 2008b.

Cross, E. S., Slowik, J., Davidovits, P., Allan, J., Worsnop, D., Jayne, J., Lewis, D., Canagaratna, M., and Onasch, T.: Laboratory and ambient particle density determinations using light scattering in conjunction with aerosol mass spectrometry, Aerosol Sci. Tech., 41(4), 343-359, 2007.

Dusek, U., Ctyroky, P., Reischl, G., and Hitzenberger, R.: CCN activation of pure and coated carbon black particles, Environ. Sci. Technol. 40, 1223-1230, 2006a.

Dusek, U., Frank, G. P., Hildebrandt, L., Curtius, J., Schneider, J., Walter, S., Chand, D., Drewnick, F., Hings, S., Jung, D., Borrmann, S., and Andreae, M. O.: Size matters more than chemistry for cloud-nucleating ability of aerosol particles, Science, 312, 1375, 2006b.

Forrer, J., Rüttimann, R., Schnciter, D., Fischer, A., Buchmann, B., and Hofer, P.: Variability of trace gases at the high-Alpine site Jungfraujoch caused by meteorological transport processes, J. Geophys. Res., 105(D10), 12241-12251, doi:10.1029/1999JD901178, 2000.

Gao, R. S., Schwarz, J. P., Kelly, K. K., Fahey, D. W., Watts, L. A., Thompson, T. L., Spackman, J. R., Slowik, J. G., Cross, E. S., Han, J.-H., Davidovits, P., Onasch, T. B., and Worsnop, D. R.: A novel method for estimating light-scattering properties of soot aerosols using a modified single-particle soot photometer, Aerosol Sci. Tech., 41, 125-135, 2007.

Hansen, J. and Nazarenko, L.: Soot climate forcing via snow and ice albedos, Proc. Natl Acad. Sci. USA ,101, 423-428, 2004.

Harris, S. and Maricq, M.: Signature size distributions for diesel and gasoline engine exhaust particulate matter, J. Aerosol Sci., 32, 749-764, 2001.

Hendricks, J., Kärcher, B., Döpelheuer, A., Feichter, J., Lohmann, U., and Baumgardner, D.: Simulating the global atmospheric black carbon cycle: a revisit to the contribution of aircraft emissions, Atmos. Chem. Phys., 4, 2521-2541, doi:10.5194/acp-42521-2004, 2004.

Henning, S. E., Weingartner, E., Schmidt, S., Wendisch, M., Gäggeler, H. W., and Baltensperger, U.: Size-dependent aerosol activation at the high-alpine site Jungfraujoch ( $3580 \mathrm{~m}$ a.s.1.), Tellus B, 54, 82-95, 2002.

Henning, S., Bojinski, S., Diehl, K., Ghan, S., Nyeki, S., Weingartner, E., Wurzler, S., and Baltensperger, U:: Aerosol partitioning in natural mixed-phase clouds, Geophys. Res. Lett., 31, L06101, doi:10.1029/2003GL019025, 2004.

Henson, B. F.: An adsorption model of insoluble particle activation: Application to black carbon, J. Geophys. Res., 112, D24S16, doi:10.1029/2007JD008549, 2007.

Holloway, T., Levy II, H., and Kasibhatla, P.: Global distribution of carbon monoxide, J. Geophys. Res., 105(D10), 12123-12147, 2000.

Jacobson, M. Z.: Analysis of aerosol interactions with numerical techniques for solving coagulation, nucleation, condensation, dissolution, and reversible chemistry among multiple size distributions, J. Geophys. Res., 107(D19), 4366, doi:10.1029/2001JD002044, 2002.

Jacobson, M. Z.: Climate response of fossil fuel and biofuel soot, accounting for soot's feedback to snow and sea ice albedo and emissivity, J. Geophys. Res., 109, D21201, doi:10.1029/2004JD004945, 2004.

Jacobson, M. Z.: Effects of externally-through-internally-mixed soot inclusions within clouds and precipitation on global climate, J. Phys. Chem. A., 110, 6860-6873, 2006.

Kärcher, B., Möhler, O., DeMott, P. J., Pechtl, S., and Yu, F.: Insights into the role of soot aerosols in cirrus cloud formation, Atmos. Chem. Phys., 7, 4203-4227, doi:10.5194/acp-7-4203-2007, 2007.

Kittelson, D. B., Watts, W. F., and Johnson, J. P.: Nanoparticle emissions on Minnesota highways, Atmos. Environ., 38, 9-19, 2004.

Kondo, Y., Komazaki, Y., Miyazaki, Y., Moteki, N., Takegawa, N., Kodama, D., Deguchi, S., Nogami, M., Fukuda, M., Miyakawa, T., Morino, Y., Koike, M., Sakurai, H., Ehara, and K.: Temporal variations of elemental carbon in Tokyo, J. Geophys. Res., 111, D12205, doi:10.1029/2005JD006257, 2006.

Lack, D. A., Cappa, C., Covert, D., Baynard, T., Massoli, P., Sierau, B., Bates, T., Quinn, P., Lovejoy, E., and Ravishankara, A.: Bias in filter-based aerosol light absorption measurements due to organic aerosol loading: Evidence from ambient measurements, Aerosol Sci. Tech., 42(12), 1033-1041, 2008.

Liu, L. and Mishchenko, M. I.: Effects of aggregation on scattering and radiative properties of soot aerosols, J. Geophys. Res., 110, D11211, doi:10.1029/2004JD005649, 2005.

Lohmann, U.: A glaciation indirect aerosol effect caused by soot aerosols, Geophys. Res. Lett., 29(4), 1052 , doi:10.1029/2001GL014357, 2002.

Lugauer, M., Baltensperger, U., Furger, M., Gäggeler, H. W., Jost, D. T., Schwikowski, M., and Wanner, H.: Aerosol particle transport to the high alpine sites Jungfraujoch (3454 $\mathrm{m}$ a.s.1.) and Colle Gnifetti (4452 m a.s.1.), Tellus B, 50, 76-92, 1998.

Lugauer, M., Baltensperger, U., Furger, M., Gäggeler, H. W., Jost, D. T., Nyeki, S., and Schwikowski, M.: Influences of vertical transport and scavenging on aerosol particle surface area and radon decay product concentrations at the Jungfraujoch (3454 m a.s.1.), J. Geophys. Res.-Atmos., 105, 19869-19879, 2000.

McFiggans, G., Artaxo, P., Baltensperger, U., Coe, H., Facchini, M. C., Feingold, G., Fuzzi, S., Gysel, M., Laaksonen, A., Lohmann, U., Mentel, T. F., Murphy, D. M., O’Dowd, C. D., Snider, J. R., and Weingartner, E.: The effect of physical and chemical aerosol properties on warm cloud droplet activation, Atmos. Chem. Phys., 6, 2593-2649, doi:10.5194/acp-6-2593-2006, 2006.

Moteki, N. and Kondo, Y.: Effects of mixing state on black car- 
bon measurements by laser-induced incandescence, Aerosol Sci. Tech., 41(4), 398-417, 2007.

Moteki, N., Kondo, Y., Miyazaki, Y., Takegawa, N., Komazaki, Y., Kurata, G., Shirai, T., Blake, D. R., Miyakawa, T., and Koike, M.: Evolution of mixing state of black carbon particles: Aircraft measurements over the western Pacific in March 2004, Geophys. Res. Lett., 34, L11803, doi:10.1029/2006GL028943, 2007.

Petzold, A. and Schönlinner, M.: Multi-angle absorption photometry - a new method for the measurement of aerosol light absorption and atmospheric black carbon, J. Aerosol Sci., 35, 421-441, 2004.

Petzold, A., Gysel, M., Vancassel, X., Hitzenberger, R., Puxbaum, H., Vrochticky, S., Weingartner, E., Baltensperger, U., and Mirabel, P.: On the effects of organic matter and sulphurcontaining compounds on the $\mathrm{CCN}$ activation of combustion particles, Atmos. Chem. Phys., 5, 3187-3203, doi:10.5194/acp-53187-2005, 2005.

Raes, F., Van Dingenen, R., Vignati E., Wilson, J., Putaud, J. P., Seinfeld, J. H., and Adams, P.: Formation and cycling of aerosols in the global troposphere, Atmos. Environ., 34, 4215-4240, 2000.

Ramanathan, V. and Carmichael, G.: Global and regional climate changes due to black carbon, Nat. Geosci., 1, 221-227, 2008.

Reimann, S., Vollmer, M. K., Folini, D., Steinbacher, M., Hill, M., Buchmann, B., Zander, R., Mahieu, E.: Observations of Anthropogenic Halocarbons at the High-Alpine site of Jungfraujoch for assessment of trends and European sources, Sci. Tot. Environ., 391, 224-231, 2008.

Schröder, F. P., Kärcher, B., Fiebig, M., and Petzold, A.: Aerosol states in the free troposphere at northern midlatitudes, J. Geophys. Res., 107(D21), 8126, doi:10.1029/2000JD000194, 2002.

Schüepp, M., Klimatologie der Schweiz, Band II, Witterungsklimatologie, 94 pp., Schweiz. Meteorol. Anst., Ztirich, Switzerland, 1979.

Schwarzschild, J. P., Gao, R. S., Fahey, D. W., Thomson, D. S., Watts, L. A., Wilson, J. C., Reeves, J. M., Baumgardner, D. G., Kok, G. L., Chung, Schulz, S. M., Hendricks, J., Lauer, A., Kärcher, B., Slowik, J. G., Rosenlof, K. H., Thompson, T. L., Langford, A. O., Lowenstein, M., and Aikin, K. C.: Single-particle measurements of midlatitude black carbon and light-scattering aerosols from the boundary layer to the lower stratosphere, J. Geophys. Res., 111, D16207, doi:10.1029/2006JD007076, 2006.

Schwarz, J. P., J. R. Spackman, D. W. Fahey, R. S. Gao, U. Lohmann, P. Stier, L. A. Watts, D. S. Thomson, D. A. Lack, L. Pfister, M. J. Mahoney, D. Baumgardner, J. C. Wilson, and J. M. Reeves: Coatings and their enhancement of black-carbon light absorption in the tropical atmosphere, J. Geophys. Res., 113, D03203, doi:10.1029/2007JD009042, 2008a.

Schwarzschild, J. P., Gao, R. S., Spackman, J. R., Watts, L. A., Thomson, D. S., Fahey, D. W., Ryerson, T. B., Peischl, J., Holloway, J. S., Trainer, M., Frost, G. J., Baynard, T., Lack, D. A., de Gouw, J. A., Warneke, C., and Del Negro, L. A.: Measurement of the mixing state, mass, and optical size of individual black carbon particles in urban and biomass burning emissions, Geophys. Res. Lett., 35, L13810, doi:10.1029/2008GL033968, 2008b.

Schwarz, J. P., Spackman, J. R., Gao, R. S., Perring, A. E., Cross, E., Onasch, T. B., Ahern, A., Wrobel, W., Davidovits, P., Olfert, J., Dubey, M. K., Mazzoleni, C., and Fahey, D. W.: The detection efficiency of the single particle soot photometer, Aerosol
Sci. Technol., 44, 612-628, doi:10.1080/02786826.2010.481298, 2010

Seibert, P., Kromp-kolb, H., Kasper, A., Kalina, M., Puxbaum, H., Jost, D., Schwikowski, M., and Baltensperger, U.: Transport of polluted boundary layer air from the Po Valley to high alpinesites. Atmos. Environ., 32, 3953-3965, 1998.

Sjogren, S., Gysel, M., Weingartner, E., Alfarra, M. R., Duplissy, J., Cozic, J., Crosier, J., Coe, H., and Baltensperger, U.: Hygroscopicity of the submicrometer aerosol at the high-alpine site Jungfraujoch, $3580 \mathrm{~m}$ a.s.l., Switzerland, Atmos. Chem. Phys., 8, 5715-5729, doi:10.5194/acp-8-5715-2008, 2008.

Slowik, J. G., E. Cross, J. Han, P. Davidovits, T. B. Onasch, J. T. Jayne, L. R. Williams, M. R. Canagaratna, D. R. Worsnop, R. K. Chakrabarty, W. P. Arnott, J. P. Schwarz, R. S. Gao, D. W. Fahey, and G. L. Kok: An intercomparison of instruments measuring black carbon content of soot particles, Aerosol Sci. Technol., 41, 295, 2007.

Spackman, J. R., Schwarz, J. P., Gao, R. S., Watts, L. A., Thomson, D. S., Fahey, D. W., Holloway, J. S., de Gouw, J. A., Trainer, M., and Ryerson, T. B.: Empirical correlations between black carbon aerosol and carbon monoxide in the lower and middle troposphere, Geophys. Res. Lett., 35, L19816, doi:10.1029/2008GL035237, 2008.

Stephens, M., Turner, N., and Sandberg, J.: Particle identification by laser induced incandescence in a solid state laser cavity, Appl. Optics, 42, 3726-3736, 2003.

Subramanian, R., Roden, C. A., Boparai, P., and Bond, T. C : Yellow beads and missing particles: Trouble ahead for filter-based absorption measurements, Aerosol Sci. Tech., 41, 630-637, 2007.

Targino, A. C., Coe, H., Cozic, J., Crosier, J., Crawford, I., Bower, K., Flynn, M., Gallagher, M., Allan, J., Verheggen, B., Weingartner, E., Baltensperger, U., and Choularton, T.: Influence of particle chemical composition on the phase of cold clouds at a high-alpine site in Switzerland, J. Geophys. Res., 114, D18206, doi:10.1029/2008JD011365, 2009.

Textor, C., Schulz, M., Guibert, S., Kinne, S., Balkanski, Y., Bauer, S., Berntsen, T., Berglen, T., Boucher, O., Chin, M., Dentener, F., Diehl, T., Easter, R., Feichter, H., Fillmore, D., Ghan, S., Ginoux, P., Gong, S., Grini, A., Hendricks, J., Horowitz, L., Huang, P., Isaksen, I., Iversen, I., Kloster, S., Koch, D., Kirkevåg, A., Kristjansson, J. E., Krol, M., Lauer, A., Lamarque, J. F., Liu, X., Montanaro, V., Myhre, G., Penner, J., Pitari, G., Reddy, S., Seland, Ø., Stier, P., Takemura, T., and Tie, X.: Analysis and quantification of the diversities of aerosol life cycles within AeroCom, Atmos. Chem. Phys., 6, 1777-1813, doi:10.5194/acp-61777-2006, 2006.

Turpin, B. J. and Huntzicker, J. J.: Identification of secondary organic aerosol episodes and quantitation of primary and secondary organic aerosol concentrations during SCAQS, Atmos. Environ., 29, 3527-3544, 1995.

Verheggen, B., Cozic, J., Weingartner, E., Bower, K., Mertes, S., Connolly, P., Gallagher, M., Flynn, M., Choularton, T., and Baltensperger, U.: Aerosol partitioning between the interstitial and the condensed phase in mixed-phase clouds, J. Geophys. Res., 112, D23202, doi:10.1029/2007JD008714, 2007.

Wanner, H., Salvisberg, E., Rickli, R., and Schüepp, M.: 50 years of Alpine Weather Statistics (AWS), Meteorol. Z., 7, 99-111, 1998.

Weingartner, E., Baltensperger, U., and Burtscher, H.: Growth and structural change of combustion aerosols at high Relative $\mathrm{Hu}-$ 
midity, Environ. Sci. Tech., 29(12), 2982-2986, 1995.

Weingartner, E., Burtscher, H., and Baltensperger, U.: Hygroscopic properties of carbon and diesel soot particles, Atmos. Environ., 31, 2311-2327, 1997.

Weingartner, E., Nyeki, S., and Baltensperger, U.: Seasonal and diurnal variation of aerosol size distributions $(10<\mathrm{D}<750 \mathrm{~nm})$ at a high-alpine site (Jungfraujoch $3580 \mathrm{~m}$ a.s.l.), J. Geophys. Res., 104, 26809-26820, 1999.
Zellweger, C., Forrer, J., Hofer, P., Nyeki, S., Schwarzenbach, B., Weingartner, E., Ammann, M., and Baltensperger, U.: Partitioning of reactive nitrogen (NO) and dependence on meteorological conditions in the lower free troposphere, Atmos. Chem. Phys., 3, 779-796, doi:10.5194/acp-3-779-2003, 2003. 